\title{
Basel Compliance and Financial Stability: Evidence from Islamic Banks
}

\section{Mohammad Bitar $^{1}$ (D) Sami Ben Naceur ${ }^{2} \cdot$ Rym Ayadi $^{3} \cdot$ Thomas Walker $^{4}$}

Received: 18 October 2018 / Revised: 24 May 2020 / Accepted: 28 May 2020

Published online: 15 September 2020

(C) The Author(s) 2020

\begin{abstract}
We find that compliance with the Basel Core Principles (BCPs) has a strong positive effect on the stability of conventional banks, and a positive but less pronounced effect on the stability of Islamic banks. We also find that the main impact of compliance is an increase in capital ratios, whereas other components of the Z-score are negatively affected. This reflects the desire of banks to be more closely integrated into the global financial system by holding higher capital ratios. The findings also justify the 2015 decision of the Islamic Financial Services Board to publish similar principles for Islamic banks.
\end{abstract}

\section{JEL Classification Numbers G18·G21 P51}

Keywords BCPs $\cdot$ Core principles for Islamic finance regulation $\cdot$ Stability $\cdot$ Islamic banks

The views expressed here are those of the authors, and the paper does not represent the views of the IMF, its Executive Board or its management.

Mohammad Bitar

mohammad.bitar@nottingham.ac.uk

Sami Ben Naceur

sbennaceur@imf.org

Rym Ayadi

rym.ayadi@ city.ac.uk

Thomas Walker

thomas.walker@concordia.ca

1 Nottingham University, Nottingham, UK

2 International Monetary Fund, Washington, D.C., USA

3 Cass Business School, London, UK

4 Concordia University in Canada, Montreal, Canada 


\section{Introduction}

In this study, we examine whether compliance with the Basel Core Principles (BCPs) for effective banking supervision affects the stability and risk taking of conventional and Islamic banks. In prior studies, Demirgüç-Kunt and Detragiache (2011) and Ayadi et al. (2016) have examined the effects of BCP compliance using large and heterogeneous samples of conventional banks around the world. In this paper we extend their analyses to include Islamic banks. We also focus on a more homogeneous sample in the sense that the banks in our study operate mainly in developing and emerging countries.

The BCPs were introduced in 1997 by the Basel Committee on Banking and Supervision (BCBS). Since then, several surveys have been conducted by the International Monetary Fund (IMF) and the World Bank to assess the quality of banking regulation and supervision worldwide under the Basel principles. The principles were initially created as a pilot project for 12 advanced countries, but they rapidly became the global standard for banking regulation. BCPs include 25 principles organised into 7 chapters (i.e., each chapter contains a few of the 25 principles). However, one important drawback of the BCPs is that they do not take into account the distinctive characteristics of certain types of bank such as Islamic banks. ${ }^{1}$

In 2015, the Islamic Financial Services Board (IFSB), ${ }^{2}$ an international regulatory organization that was created to promote the development and the stability of the Islamic financial industry, published a set of guidelines called the Core Principles for Islamic Finance Regulation (CPIFRs). These guidelines are built on BCBS standards and have been extended to deal with the characteristics of Islamic banks.

Within these guidelines, some of the CPIFRs replicate and fully reflect the Basel principles, some represent amendments to the BCPs, and some CPIFRs are completely new. Because the CPIFR guidelines were published in 2015, Islamic banks were not expected to implement them before January 2016 and in many cases even later (IFSB 2015). Thus, data on Islamic bank compliance with the CPIFRs are not available at this stage. However, since some of the CPIFRs are similar to conventional bank BCPs, and there are data available on the compliance of Islamic banks with those principles, our study examines whether the adoption of the BCPs has affected the stability of Islamic banks. This enables us to make some plausible predictions about the expected effects of the CPIFRs on the financial soundness of Islamic banks.

To examine these issues, we use a sample of 761 conventional and Islamic banks operating in 19 countries and covering the period from 1999 to 2013. In contrast to Demirgüç-Kunt and Detragiache (2011), our findings suggest that BCP compliance is positively associated with the stability of conventional banks (at the $1 \%$ significance level) and that this holds true for at least five of the seven

\footnotetext{
${ }^{1}$ Islamic banks are by nature financial intermediaries that are compliant with Sharia'a law (Gheeraert 2014). Thus, they can be defined as institutions that allocate resources and invest them under the guidance of Sharia'a principles without the use of interest. Islamic banks operate in a highly regulated industry. However, due to the special characteristics of Islamic banks - i.e. the concept of profit and loss sharing at both the asset side (with entrepreneurs/borrowers) and the liability side (with depositors/investors) - they not only adhere to the Basel Committee on Banking and Supervision (BCBS) regulatory guidelines but also to specific capital guidelines by the Islamic Financial Services Board (IFSB) and the Accounting and Auditing Organization for Islamic Financial Institutions (AAOIFI). In this paper, we do not detail the characteristics of Islamic banks because they were already reviewed extensively in the previous literature. For excellent reviews, the reader may refer to Khan (2010), Beck et al. (2013), and Abedifar et al. (2013).

${ }^{2}$ Established in Kuala Lumpur, Malaysia, in 2002, the Islamic Financial Services Board (IFSB) comprises 188 members, including 61 regulatory authorities, 8 intergovernmental organizations, and 119 market players. The IFSB is considered to be the complement of the Basel Committee on Banking Supervision.
} 
chapters that make up the BCP. The effect remains positive but less pronounced for Islamic banks, where the effects of compliance are positive and significant at the $5 \%$ level or better for three of the seven chapters. A deeper examination of the components of the main dependent variable (bank Zscores) shows that the component of stability most influenced by compliance is the bank capital ratio. The findings indicate that adherence to international regulatory standards improves the stability of the two bank types through incentives to hold higher capital ratios. The results hold when controlling for bank financial characteristics, as well as for the macroeconomic and institutional environment. The findings also remain invariant (i) across sub-samples representing different regions, economic cycles, market disciplines, and political and institutional environments, (ii) when employing alternative measures of risk and stability, (iii) when using an instrumental variables approach and the Heckman estimation technique to address potential endogeneity and selection biases, and (iv) when using propensity score matching (PSM) to reduce any biases due to the limited sample size.

This study contributes to the literature on both conventional and Islamic banks in at least three important ways. First, we highlight a strong positive impact of the BCP index on the stability of conventional banks, while the effect remains positive but somewhat weaker for Islamic banks. This provides regulatory organizations such as the Bank for International Settlements (BIS) and the IFSB with initial empirical evidence to support the effective role of BCP standards in improving bank stability. Given that the BCPs are also effective in improving the stability of Islamic banks, it is likely that the CPFIRs will positively affect the stability of those banks, as the CPFIRs are modelled closely on the BCPs.

Second, we show that regulatory compliance enhances bank stability through two main mechanisms: (i) the tendency to make prudent investment decisions, which avoid risky activities and thereby result in lower but more stable returns on assets; and (ii) the maintenance of strong insolvency ratios driven by the desire of banks in developing countries to be recognized and better integrated into the global financial system.

Finally, we add to the comparative literature on conventional and Islamic banks (Abedifar et al. 2013; Mollah et al. 2017; Bitar et al. 2017; Bitar and Tarazi 2019) by exploring the regulatory determinants of bank stability and by documenting compelling evidence that the two bank types respond to similar determinants.

The remainder of this paper is structured as follows: Section II briefly reviews the literature. Section III describes the sample, outlines our empirical approach, and provides variable definitions. Section IV presents the main results, while Section V examines the robustness of the findings. The last section provides a brief summary and comments on future directions for the research.

\section{Literature Review}

The literature examining the effect of banking regulation on the risks to, and the stability of, the financial system does not employ a consistent set of indicators that can be used as a proxy for banking regulation. While some studies make use of accounting and market ratios such as regulatory capital, liquidity, and leverage measures, others use proxies based on questionnaires and surveys administered by governments and international regulatory organizations. These studies often report inconclusive and contradictory results.

Barth et al. (2004, 2006, and 2008) were among the first to examine the effect of banking regulation and supervision on bank performance and stability using international data. Their 
findings suggest that strong monitoring of markets and the private sector is an important factor in promoting the performance and stability of the financial sector. Focusing on corporate governance, Leaven and Levine (2009) examine the effects of banking regulation and supervision using a variety of proxies (capital requirements, capital stringency, activity restrictions, and deposit insurance), while also considering bank ownership structure. They conclude that regulation increases bank risk-taking when a bank has an ultimate owner, while the opposite occurs when a bank is widely held. Klomp and de Haan (2012) investigate whether banking regulation has a homogeneous effect on bank risk. Using a sample of 200 banks from 21 OECD countries, their findings show that banking regulation is more effective in improving safety for riskier banks; i.e., the effect of regulation is not uniform and depends on a bank's risk profile. Klomp and de Haan (2014) extend this investigation by examining whether the association between banking regulation and risk varies with the level of development of a country's institutional environment. Using a sample of 400 banks from 70 developing and emerging countries, their findings indicate that the positive effect of banking regulation and supervision on risk avoidance is enhanced in countries with a better institutional environment.

More recently, Doumpos et al. (2015) use a large sample of 1700 commercial banks operating in 90 countries over the period 2000-2011 to study the effect of three indices of regulation (central bank independence, central bank involvement in prudential regulation, and supervisory unification) on bank stability. Depending on bank size and the country's official supervisory power, their results yield a positive and significant association with bank Z-scores, especially during periods of crisis. Finally, using a sample of 19 EU countries covering the 1999-2011 period, Carretta et al. (2015) investigate whether the culture of banking supervision (proxied by Hofstede's cultural dimensions) affects the stability of banks. Their findings suggest that so-called supervisory cultures, i.e. cultures based on collectivism and avoidance of uncertainty, are positively correlated with bank Z-scores. Accordingly, they highlight the importance of cultural dimensions when evaluating the success of banking regulation by the European Central Bank (ECB).

A serious shortcoming of these studies is that they evaluate the effectiveness of banking regulation and supervision based on what is claimed in the banks' books rather than on an objective assessment of whether, and to what extent, these regulations are actually implemented (Demirgüç-Kunt and Detragiache 2011; Ayadi et al. 2016). Such an assessment often reveals a lack of proper implementation, especially in developing countries, so that the variation across different countries according to the banks' books may underestimate the true variation in the execution of banking regulations (Demirgüç-Kunt and Detragiache 2011).

A small but growing stream of literature utilizes the BCP index to assess the quality of banking supervision as an alternative to measures based on questionnaires and surveys (as reported above). Developed by the World Bank and the IMF under the Basel Core Financial Sector Assessment Program (FSAP), the BCP index is considered a unique source of information that represents the quality of supervision and regulation in countries around the globe. Demirgüç-Kunt and Detragiache (2011) argue that assessments by the FSAP are reliable for two reasons: First, the BCP index reflects the actual implementation of the different elements of banking regulation and supervision. Second, assessments are based on an explicit and standardized methodology and are conducted by experienced international assessors with broad country experience. ${ }^{3}$

\footnotetext{
${ }^{3}$ However, BCP assessments cannot be considered an exact science, as the evaluations might be affected by several factors depending on the assessors' subjectivity and experience as well as the existing regulatory framework (Demirgüç-Kunt and Detragiache 2011; Ayadi et al. 2016).
} 
Several studies have employed the BCP index as a proxy measure of regulatory compliance and have used it to examine the effect of compliance on the performance and stability of the banking system. Sundararajan et al. (2001) examine the association between BCP compliance and bank soundness, using a sample of banks in 25 countries. Their findings highlight the importance of other bank-level and macroeconomic factors and demonstrate that the implementation of international standards is not sufficient in itself to ensure financial soundness. Demirgüç-Kunt et al. (2008) find that countries that comply with the BCP requirements for information disclosure receive higher financial strength ratings from Moody's. In addition, Podpiera (2006) investigates the effect of BCP compliance on bank performance using a sample of banks from advanced, emerging, and developing countries. He finds that banks in countries with higher compliance have lower levels of non-performing loans and lower net interest margins. In a similar study, Cihak and Tieman (2008) show that BCP compliance is positively and strongly associated with a country's level of governance and GDP per capita, while the effect is less significant when replacing the BCP index with on-the-book regulatory measures. Demirgüç-Kunt and Detragiache (2011) investigate the association between BCP compliance and financial stability for a sample of international banks. Employing an overall compliance index, the authors find no evidence of a significant relationship between the index and the banks' Z-scores. Finally, Ayadi et al. (2016) extend the work of Demirgüç-Kunt and Detragiache (2011) by focusing on bank efficiency. Their results show no association between BCP compliance and efficiency. Table 1 summarises the available literature on BCP studies.

Given that the BCPs are designed to promote the stability and financial soundness of conventional banks, it might be argued that the likelihood of BCP compliance having an effect on the stability of Islamic banks would be negligible or, at best, relatively slim. This conclusion is predicated on the assumption that Islamic banks have different balance sheets and different financial products from conventional banks. However, the literature offers a variety of opinions on whether or not, in practice, Islamic banks share the same financial characteristics as conventional banks. The main reason for the differences of opinion is that the current business models of Islamic banks are inconsistent, such that in some cases there is a significant disjunction between Sharia'a ideals and bank practices (Khan 2010). One would expect that under Sharia'a law, Profit Loss Sharing (PLS) instruments such as Musharaka and Moudharaba (core elements of Islamic banking and finance) would dominate Islamic banking practices. Yet, surprisingly, non-PLS mark-up modes of finance, such as Murabaha and Ijara, predominate. Mark-up financing techniques are considered less Sharia'a compliant and are seen as the hallmark of conventional banking; hence their predominance in the Islamic sector suggests that the two bank types may in fact be quite similar (Abedifar et al. 2013; Beck et al. 2013; Bitar and Tarazi 2019).

Recently, the IFSB published new guidelines, the CPIFRs (IFSB 2015), which are based on the Basel Core Principles for effective banking supervision. According to the IFSB, the proposed guidelines aim to "build on the standards adopted by relevant conventional standards [...] and to adapt or supplement them only to the extent necessary to deal with the specificities of Islamic finance" (IFSB 2015, p. 2). A detailed description of the CPIFRs is presented in Table 12 .

CPIFR guidelines differ from BCP guidelines in at least three main respects. First, in the CPIFR framework, investment account holders (IAHs) are treated more like investors than depositors. This has an impact on capital adequacy ratios, the results of the relevant risk weighting methodology, the role of regulatory authorities in capital treatment, the bank's smoothing behavior, and the bank's exposure to displaced commercial risk. Second, the rate of 


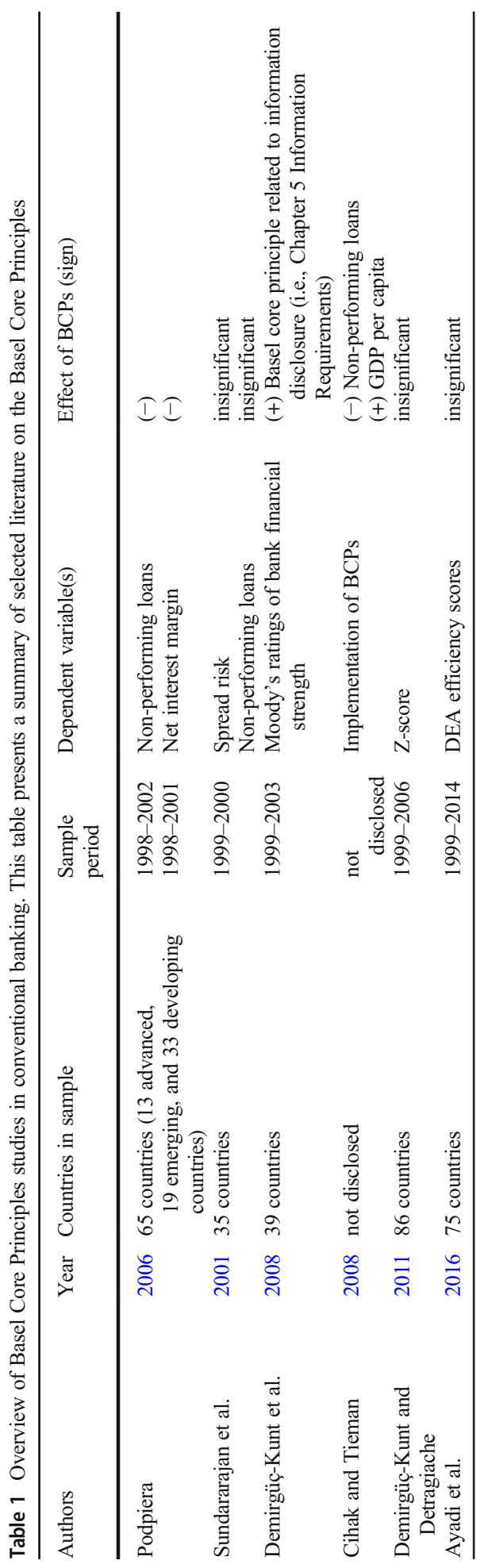


return (ROR) risk differs in that it depends on market conditions and on competition with conventional banks. The ROR might lead to the use of bank reserves or to displaced commercial risk (DCR) if an Islamic bank absorbs any losses (partially or entirely), if reducing its share of profits yields a shortcoming in the returns payable to IAHs, or through a donation from the shareholders' share of income. Finally, the CPIFRs stipulate that Islamic banks must possess an effective Sharia'a governance system to ensure the compliance of the banks' activities, investments and products with Islamic law; obviously, the BCP guidelines do not include this requirement.

As mentioned above, differences between Islamic and conventional banks might influence the extent to which BCP compliance affects the stability of Islamic banks compared to their conventional counterparts. While CPIFRs take these differences into account, an empirical investigation of the effect of CPIFRs on the stability of Islamic banks is not possible at this stage because CPIFRs have only been introduced recently. We thus substitute compliance with the BCPs (measured by the BCP index) for CPIFR compliance, and we argue that the BCPs should have a similar effect to the CPIFRs for two reasons: First, according to the IFSB (2015), seven principles in the CPIFR guidelines were kept the same as the BCPs, seventeen principles were amended, and only one principle was replaced. The main difference resides in four new CPIFR principles related to the characteristics of Islamic banks that were not considered in the BCP guidelines. Second, given that CPIFR guidelines resemble BCP guidelines, they are likely to have similar effects on banks with similar characteristics - and the literature suggests that the two bank types are indeed fairly similar (or at least not very different) in terms of business orientation (Beck et al. 2013), stability and interest (financing) margins (Abedifar et al. 2013), profitability (Mollah and Zaman 2015), and capital structure (Bitar and Tarazi 2019).

\section{Data and Methodology}

\subsection{Sample Construction}

In order to investigate the effect of the Basel Core Principles on the stability and risk of conventional and Islamic banks, we compile data from three main sources: (1) the IMF and the World Bank Basel Core Financial Sector Assessment Program (FSAP) database, ${ }^{4}$ which contains detailed information on country evaluation of, and compliance with, the BCPs during the period 1999-2012; (2) the World Bank's World Development Indicators (WDI) and World Governance Indicators (WGI) for macroeconomic and governance variables; and (3) the Bankscope Database provided by Bureau van Dijk and Fitch Ratings for yearly-based accounting data.

In the selection of bank-level data, we follow the comparative literature on conventional and Islamic banks (Abedifar et al. 2013; Beck et al. 2013; Bitar and Tarazi 2019) and retrieve financial information from 1999 to 2013 in 33 countries where both bank types exist. A bank is excluded from the sample if it does not have at least three continuous observations. In addition, we remove countries that have data for fewer than 4 banks (Beck et al. 2013). In contrast to Ayadi et al. (2016), our study focuses on a broad sample of listed and unlisted banks — not just

\footnotetext{
${ }^{4}$ Some assessments are publicly available through the IMF and World Bank websites. The remainder are kept confidential by the countries' authorities. In this study, we use a private database provided by the IMF which contains assessments for all countries. We thank the IMF for sharing these data.
} 
publicly listed banks - to ensure an adequate representation of Islamic banks, most of which are unlisted.

We then match bank-level information with country-level information to control for variations in a country's macroeconomic and regulatory conditions. After checking the FSAP database, we find 28 countries that provide information on their compliance with the BCPs and that are home to both types of bank. We exclude countries such as Algeria, Bosnia, Brunei, the Cayman Islands, Iran, Iraq, Qatar, Senegal, the Sudan, and Yemen because of missing information on some of the BCP chapters. Our final sample is thus reduced to 651 conventional banks and 110 Islamic banks operating in 19 countries $^{5}$ and is characterized by the homogeneity that results from these countries having similar financial characteristics and macroeconomic conditions. Some of these countries have few Islamic banks while others have many Islamic banks.

Because the IMF and the World Bank collected data on BCP chapter compliance in three different waves (1999, 2005 and 2012), our analyses are carried out as follows: (i) the 1999 data are used for the period 1999-2004, (ii) the 2005 data are used for the period 2005-2011, and (iii) the 2012 data are used for the period 2012-2013. In our sample, countries witnessed one or two assessment points. For instance, Pakistan only reported its BCP compliance in 2004. Thus, to avoid losing observations, the 2004 data are used for the period 2005-2013. Similarly, Saudi Arabia reported its BCP compliance in 2004 and 2011. Accordingly, we use the 2004 data for the period 2004-2010 and the 2011 data for the period 2011-2013.

\subsection{Empirical Approach and Definition of Variables}

The main dependent variable used to evaluate bank stability is the Z-score and the main independent variable is the country's BCP compliance index. We follow Mollah and Zaman (2015) and Bitar et al. (2016) and use random-effect GLS regressions to examine the effect of BCP compliance on bank financial stability. We prefer the GLS technique over other estimation techniques for two reasons: First, regression models such as OLS ignore the panel structure of our data. Second, our Islamic bank dummy is time-invariant and cannot be estimated using a fixed-effects methodology. Accordingly, we use the following baseline regression equations:

$$
\begin{aligned}
\text { Stability }_{i j t}=\alpha & +\beta_{1} \times B C P_{j t}+\beta_{2} \times \text { Bank_control }_{i j t-1}+\beta_{3} \times \text { Country_control }_{j t}+\sum_{t=1}^{T} \mu_{t} \\
\times & \text { Time }_{t}+\varepsilon_{i j t} \\
\text { Stability }_{i j t}= & \alpha+\beta_{1} \times \text { Islamic }_{i}+\beta_{2} \times B C P_{j t}+\beta_{3} \times B C P_{j t} \times \text { Islamic }_{i}+\beta_{4} \\
& \times \text { Bank_control }_{i j t-1}+\beta_{5} \times \text { Country_control }_{j t}+\sum_{t=1}^{T} \mu_{t} \times \text { Time }_{t}+\varepsilon_{i j t}
\end{aligned}
$$

where Stability ${ }_{i j t}$ represents the natural logarithm of the Z-score (defined below) of bank $i$ in country $j$ at time $t$, and $B C P_{j t}$ denotes the Basel Core Principles compliance index for country $j$ at time $t$ (if a country has reported its BCP compliance at least once). Bank_control ${ }_{i j t-1}$ is a

\footnotetext{
${ }^{5}$ The sample is dominated by developing countries. Two developed countries are also included: The UK and Singapore. We include these countries because they have available data on BCP chapters and are markets where both conventional and Islamic banks operate side by side.
} 
vector of bank-level control variables. Country_ control $_{j t}$ is a vector of country-level control variables. Time $e_{t}$ represents year fixed effects while $\varepsilon_{i j t}$ is a random disturbance, assumed to be normally distributed with zero mean and constant variance, $\varepsilon_{i j t} \sim i i d N\left(0, \sigma^{2}\right)$. In Equation (2), Islamic $_{i}$ is a dummy variable taking on a value of one for Islamic banks and zero for conventional banks. Finally, an interaction term is introduced between Islamic and $B C P$ to investigate whether a country's compliance with the BCP affects the stability of Islamic banks differently from the stability of their conventional counterparts.

The Z-score is defined as ([return on average assets + equity/assets]/[standard deviation of the return on average assets]) over the period $(t, t-3)$ (Groeneveld and de Vries 2009; Beck et al. 2013; Abedifar et al. 2013; Mollah et al. 2017). In our regression analysis, we use the natural logarithm of the Z-score to minimize the effects of higher values, which could represent outliers (Carretta et al. 2015). In our robustness tests, we follow Bitar et al. (2017) and use loan-loss reserves to gross loans (LLRGL), loan-loss provisions to total loans (LLPTL), nonperforming loans to gross loans (NPLGL), and the volatility of the net-interest margin (SDNIM) to examine the impact of the BCP compliance index on the stability and risk of the two bank types.

Despite the plethora of research on banking regulation and supervision, the BCP compliance index is rarely used in studies of conventional banking and, to the best of our knowledge, has never been used in an Islamic banking context. The BCP index is based on 25 principles that are considered the best measures of compliance with banking regulation and supervision. These principles are classified into seven chapters as follows: (Ch. 1) Preconditions for Effective Banking Supervision; (Ch. 2) Licensing and Structure; (Ch. 3) Prudential Regulation and Requirements; (Ch. 4) Methods of Ongoing Supervision; (Ch. 5) Information Requirements; (Ch. 6) Formal Powers of Supervisors; and (Ch. 7) Cross-Border Banking. Definitions of the different principles used to construct the seven chapters are provided in Table 13.

We use both an aggregate approach to examine the effect of the overall BCP index and a disaggregate approach, in which the effect of compliance with individual chapters on bank stability is examined. Each of the seven chapters that constitute the BCP compliance index is evaluated based on the following four-point scale: (i) noncompliant; (ii) materially noncompliant; (iii) largely compliant; and (iv) compliant. We grade each chapter by assigning a numerical value to these ratings (from one for noncompliant to four for compliant). Given that the compliance index is based on a four-point scale, we thus arrive at a variable that ranges from 25 (lowest compliance) to 100 (highest compliance).

We further allow for factors that may influence the relationship between BCP compliance and bank stability by including two vectors, one for bank characteristics and one for country-level factors. Bank_control ${ }_{i j t-1}$ is a vector that captures bank portfolio characteristics. It includes measures of bank size proxied by the natural logarithm of total assets $(\ln t a)$ and by the growth rate of total assets $(\mathrm{gta})$. We note that the first of these variables may arguably increase or decrease bank stability and risk (Houston et al. 2010; Beck et al. 2013). The growth-rate measure reflects any expansion of the bank's balance sheet during the current year (compared to the previous year). Abedifar et al. (2013) employ this ratio as a proxy for bank growth and development strategies. As they expand and develop, banks might be further exposed to information asymmetry, since a considerable increase in activity may result in weaker screening standards and lower monitoring of investments. We also include the cost to income ratio (cir) to capture any cross-bank differences in efficiency, where higher values reflect managerial inadequacies (inefficiency) and thus a tendency for banks to take more risk (Abedifar et al. 2013; Beck et al. 2013). In addition, we use the ratio of noninterest income to total operating income 
(niiti) to reflect a bank's business model and its tendency towards activity diversification. Finally, we use the ratio of liquid assets to deposits and short-term funding (ladstf) to assess sensitivity to bank runs, because banks with a higher proportion of liquid assets can be expected to experience lower bankruptcy costs, less information asymmetry, and a greater capacity to raise equity (Horváth et al. 2014).

Country_control ${ }_{j t}$ is a vector of five macroeconomic and institutional variables commonly used in the stability literature (Houston et al. 2010; Demirgüç-Kunt and Detragiache 2011; Abedifar et al. 2013; Bitar and Tarazi 2019). It includes the GDP growth rate ( $g d p g$ ) to reflect any potential cyclical behavior of the Basel regulation, the inflation rate (inf) to capture a country's general financial conditions, and the ratios of oil rent to GDP (oil), gas rent to GDP (gas), and mineral rent to GDP (mineral) ${ }^{6}$ as complementary measures of a country's economic independence, especially in relation to it being rich or poor in natural resources.

Finally, we employ the World Governance Index (wgi) as an additional measure to control for the quality of a country's political and institutional systems. Kaufmann et al. (2010) compute this index as the average of six governance dimensions (i.e., voice and accountability, political stability and absence of violence, government effectiveness, regulatory quality, rule of law, and control of corruption).

In our regression estimations, we winsorize all variables at the $1 \%$ and $99 \%$ levels to mitigate the effect of outliers. We follow Bitar and Tarazi (2019) and cluster at the bank level instead of the country level, for two reasons: First, our sample includes some countries with a much larger number of observations than others. Second, because we have 19 countries, clustering at a country level might create biased results (Nichols and Schaffer 2007).

\subsection{Descriptive Statistics}

Table 2 reports descriptive statistics for our samples of conventional and Islamic banks. Panels $\mathrm{A}$ and $\mathrm{B}$ present the mean, median, and standard deviation for the bank-level dependent and independent variables, while Panel $\mathrm{C}$ presents the summary statistics for the independent variables (i.e., the BCP compliance index and the seven chapters), and for the macroeconomic and institutional-environment control variables. Panel D presents the BCP compliance mean for each country and the corresponding year(s) of assessment.

In Panels $\mathrm{A}$ and $\mathrm{B}$, we also report the outcomes of a Wilks' lambda test $(\lambda),{ }^{7}$ a Wilcoxon-Mann-Whitney test (Wilc), and a univariate analysis of variance test (F) for the equality of means for each financial ratio. The results of the statistical tests are presented in the last three columns of each panel and suggest that conventional banks are significantly different from Islamic banks with respect to all the financial ratios (except for the ratio of loan loss reserves to gross loans). The three tests demonstrate that the most significant difference between the two bank types relates to the measure of volatility of net-interest margins (SDNIM), with Islamic banks showing greater volatility. Finally, we note that the bank types differ significantly on our main

\footnotetext{
${ }^{6}$ Oil, gas, and mineral rents mark the difference between the value of crude oil, gas, and mineral production at world prices and the total costs of production.

${ }^{7}$ Wilks' lambda is the ratio of the within-group sum of squares to the total sum of squares. It takes on values between zero and one, with lower values indicating that the ratios are more capable of differentiating between conventional and Islamic banks.
} 


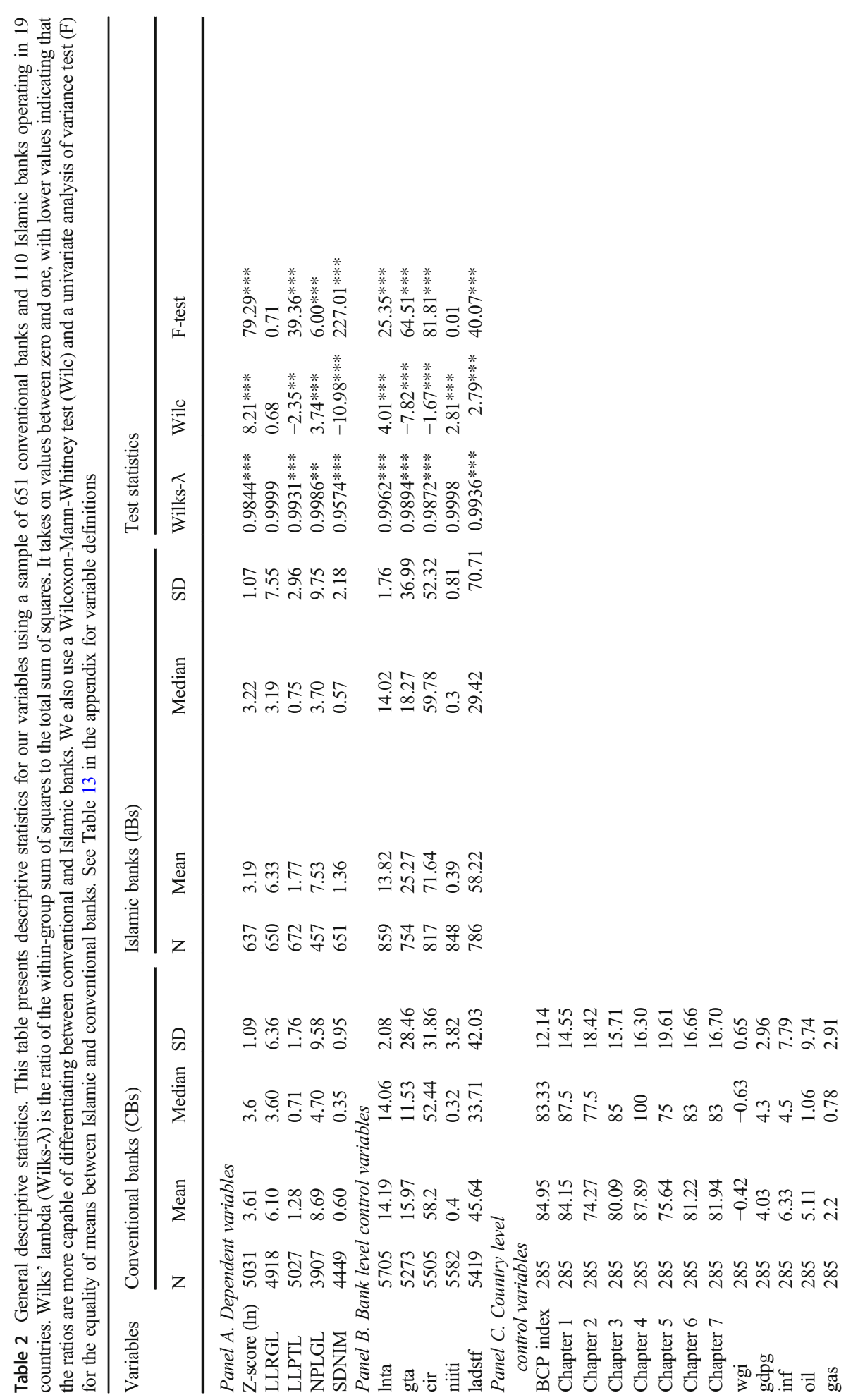




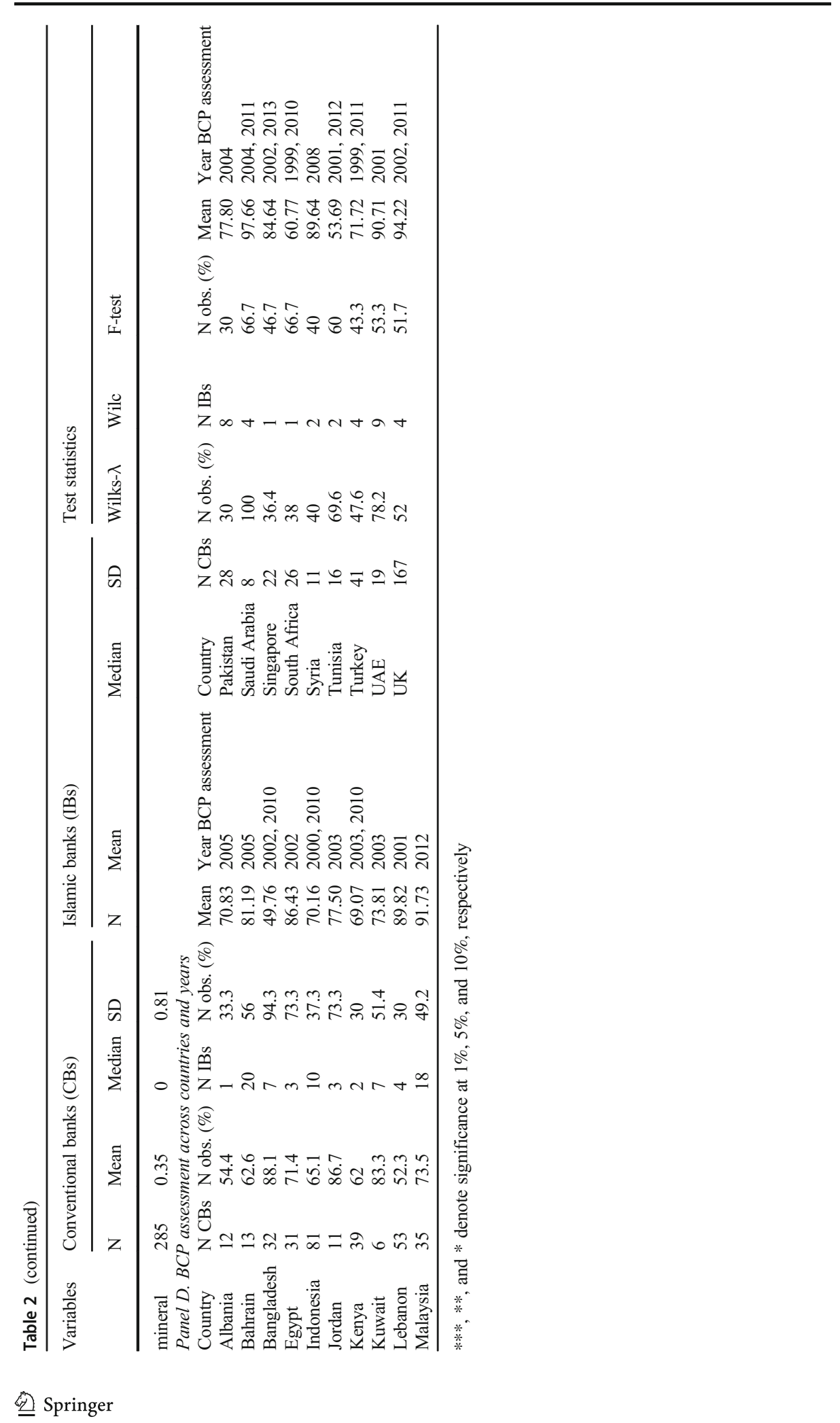


dependent variable (the Z-score) with Islamic banks exhibiting a lower degree of stability; the difference is statistically significant in all three tests.

The mean of the BCP compliance index is $84.95 \%$ (Panel C), a much higher value than that reported by Demirgüç-Kunt and Detragiache (2011) and Ayadi et al. (2016). The high percentage is likely being driven by the inclusion of a large set of banks from emerging and developing countries. Ayadi et al. (2016) argue that the BCP index is much lower in the United States and in other developed countries than in developing countries. The high mean BCP index in this study suggests that banks in developing countries are moving toward global financial convergence through their compliance with the BCPs and international regulations. Finally, Panel D presents the number of conventional and Islamic banks in each country. For conventional banks, the sample is dominated by banks from the United Kingdom, and for Islamic banks, Bahrain contributes the largest number. We also note that for our sample period, the number of available observations in Bankscope is relatively low and the percentage of the number of reported observations ( $\mathrm{N}$ obs. percent) is higher for conventional $(58.4 \%)$ than for Islamic banks (52.1\%). In other words, Bankscope provides information for conventional banks in approximately 8.8 out of our 15 sample years, while the coverage for Islamic banks is 7.8 out of 15 years.

\section{Empirical Results}

In Table 3, Panel A, we present regression results examining the effect of the BCP index on bank stability using Equations 1 and 2 after controlling for bank and country-level factors. Models 1-4 report the results for conventional banks, Models 5-8 report the results for Islamic banks, and Models 9-12 report the results for the full sample. We also present the results for the three components of the Z-score for each sample. These components comprise the ratio of return on average assets (ROAA), the standard deviation of ROAA (SDROAA), and the ratio of total equity to total assets (TETA). The Wald $\chi^{2}$ (Chi-square) tests are highly significant for all models, and the $\mathrm{R}^{2}$ values are relatively high, suggesting that the models are representative and that GLS random-effect regression is indeed an appropriate analysis technique.

We find that the BCP compliance index has a positive and significant effect on the natural logarithm of the Z-score of conventional banks (at the $1 \%$ level), Islamic banks (at the 5\% level), and the full sample (at the 1\% level). Economically, the estimated coefficients on BCP compliance in Models 1, 5, and 9 vary between 0.015 and 0.017 , indicating that a one-unit increase in the compliance index is associated with an increase of nearly two percentage points in the natural logarithm of the Zscore. In contrast to Demirgüç-Kunt and Detragiache (2011), our results indicate that the Z-score is higher for conventional and Islamic banks in countries with higher BCP compliance, suggesting that these countries have sounder institutional settings. Demirgüç-Kunt and Detragiache (2011) and Ayadi et al. (2016) used a larger and more heterogeneous set of banks in countries with different regulatory regimes and different macroeconomic and institutional conditions; these factors could explain their failure to detect an effect of BCP compliance. This study focuses mainly on countries in which the banks all operate within similar financial, economic, and institutional conditions. In addition, our sample considers banks primarily drawn from developing countries, whereas Demirgüç-Kunt and Detragiache (2011) and Ayadi et al. (2016) employ samples that are dominated by banks operating in developed countries. 


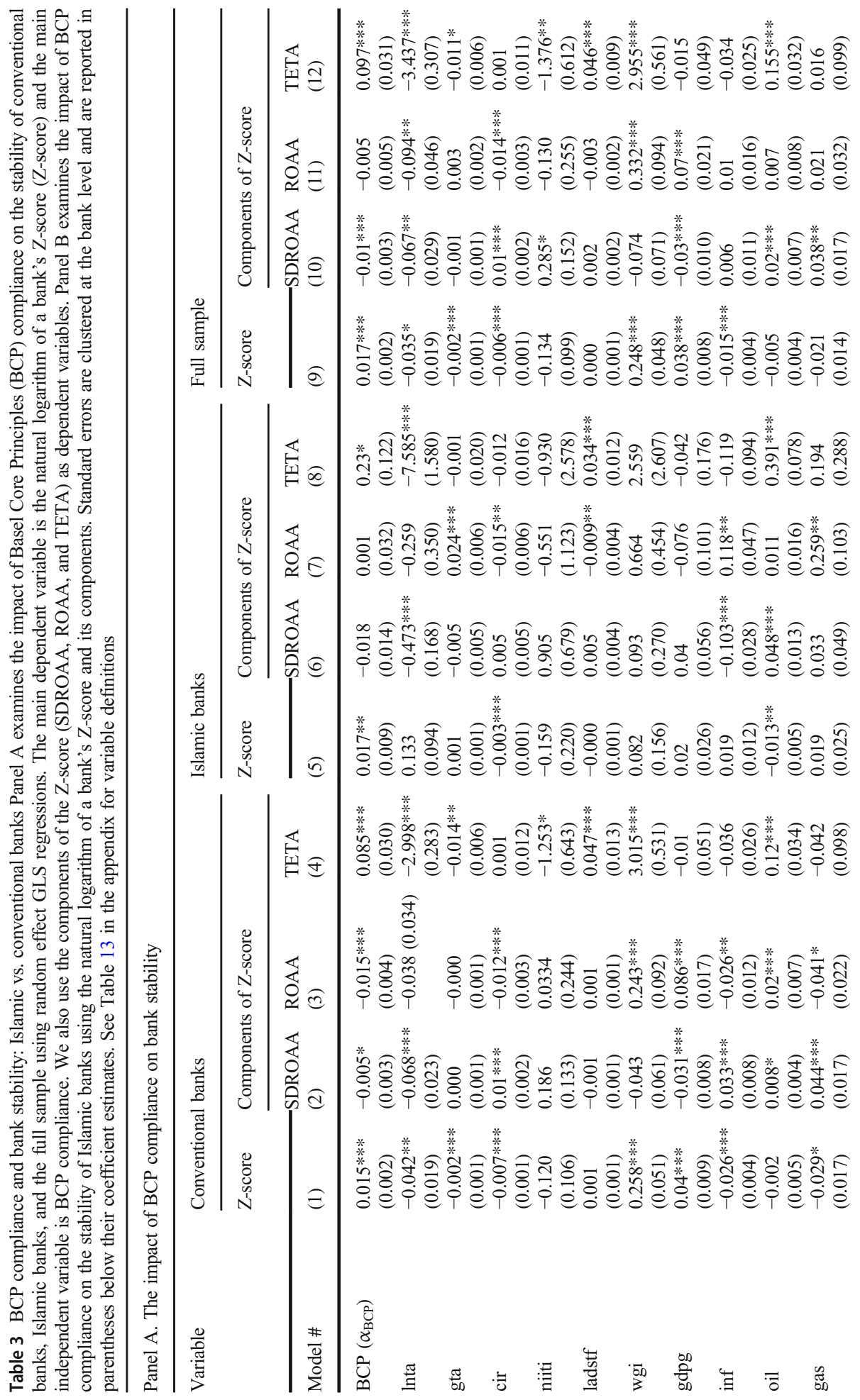




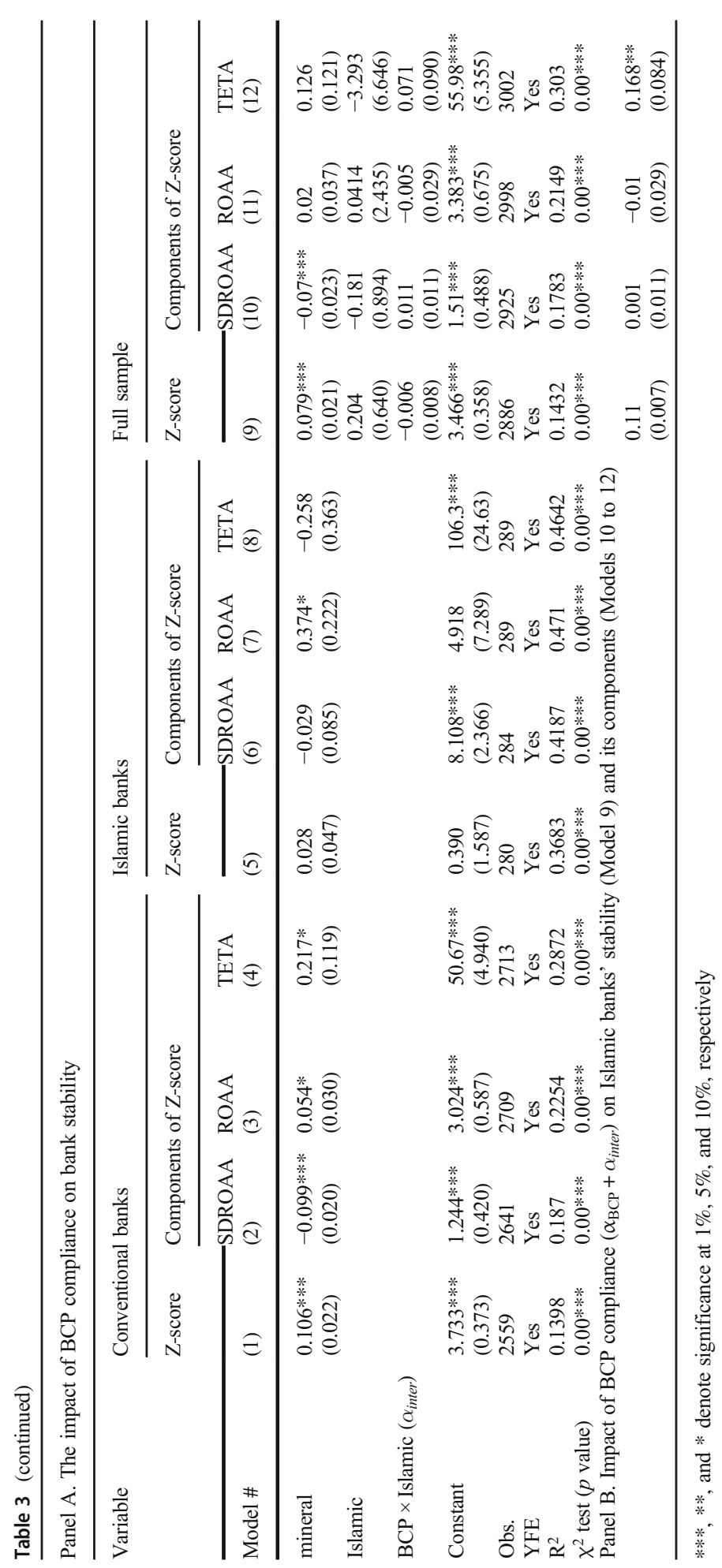


To better understand what drives the positive association between BCP compliance and bank stability, we now focus on the three components of the Z-score. This allows us to examine which components are most responsive to the effects of BCP compliance: the return on average assets, the volatility of returns, or bank capitalization. In Table 3, Models 2 and 3 respectively show a negative impact of BCP compliance on the profits of conventional banks (at the $1 \%$ level) and on the volatility of returns (at the $10 \%$ level), while in Model 4, the association with capitalization is positive and significant (at the $1 \%$ level). For Islamic banks, the results are insignificant except in Model 8, where the association between BCP compliance and bank capital is positive (at the $10 \%$ level). The results for the full sample are similar to those for conventional banks, although the coefficient estimate for the return on average assets becomes insignificant. Finally, while our findings for the full sample in Model 9 suggest that BCP compliance has a positive effect on the stability of conventional banks ( $\left[\alpha_{B C P}\right]$ is positive and significant), we do not find any significant impact of BCP compliance on the stability of Islamic banks $\left(\left[\alpha_{B C P}+\alpha_{\text {inter }}\right]\right.$, shown in Panel B, is not statistically significant). Note, however, that in Model 12, BCP compliance has a positive effect on the capital ratios of Islamic banks at the 5\% level.

Together, the findings suggest that the positive association between BCP compliance and the Zscore of the two bank types is mainly due to the incentive to hold higher capital ratios in a strong regulatory environment that discourages excessive risk taking; this acts against the generation of higher profits and earnings volatility. Findings concerning the capital ratio are consistent with the recent literature on the role of institutional and regulatory factors as determinants of bank capital decisions. For instance, Bitar and Tarazi (2018) find that creditor protection can play a powerful role in incentivizing conventional banks to increase their capital ratios.

With regard to bank-level control variables, we find that bank size and Z-scores are negatively correlated, which is likely due to the negative effect of bank size on capital for both bank types (Abedifar et al. 2013; Beck et al. 2013). We also find that the growth in total assets is negatively associated with Z-scores, reflecting weaker screening standards and fewer monitoring incentives as assets grow. This trend is in line with the fact that regulatory authorities are more flexible with large banks in terms of capital requirements - a phenomenon that also explains the negative effect of the growth of total assets on bank capital. The cost to income ratio is negatively associated with bank Zscores, suggesting that managerial inadequacies reduce bank profitability and increase risk (Abedifar et al. 2013; Beck et al. 2013). The effect of bank-level control variables is less pronounced for Islamic banks, probably due to contradictory signs of the regression coefficient for different components of the Z-score. For instance, the liquidity ratios have a negative effect on bank profits and a positive effect on bank capital, resulting in an insignificant effect on the overall Z-score. With respect to the country-level control variables, we find that banks are more stable in countries with better GDP growth, higher mineral rents, lower gas rents, and lower inflation. When decomposing the Z-score, we observe that the positive effect of GDP growth is mainly driven by the ROAA (for both conventional banks and the full sample), while the negative effect of gas rents and inflation is driven by the ROAA for the sample of conventional banks.

\section{Robustness Checks}

\subsection{BCP Index Components}

To shed further light on the main results in Table 3, we now examine the impact of the seven chapters of BCP compliance on bank stability. While Demirgüç-Kunt and Detragiache (2011) and Ayadi et al. 
(2016) examine the effect of the seven chapters in a single regression model, in this study, we separately introduce each chapter and examine its effect on bank stability, while taking account of the same bank- and country-level control variables mentioned above. In this way, we mitigate the effect of multicollinearity between the chapters on bank stability. For comparison purposes, we also report the effect of all chapters on bank Z-scores in a single regression model.

The results are presented in Table 4 where Panel A contains several important findings. First, the chapters examined in Models 2-7 all have a positive effect on conventional bank stability (at the $10 \%$ level or better). Chapter 2 on licencing and structure and Chapter 7 on cross-border banking generate the most pronounced effects on the Z-score of conventional banks, while the formal power of supervisors (Chapter 6) has the least pronounced effect. Overall, six of the seven chapters have a positive effect on the stability of conventional banks. For Islamic banks, we find positive and significant associations between the chapters incorporated in Models 10, 12, and 13 and the Z-score. Chapter 2 on licensing and structure is, again, the chapter that has the most pronounced effect on the Z-score, while Chapter 5 on information requirements generates the least pronounced effect. Overall, three of the seven chapters have a positive effect on the stability of Islamic banks. Second, if we compare the results with those obtained when all chapters are incorporated in a single model (see Models 8, 16, and 24), the findings become less pronounced for both conventional and Islamic banks and are similar to those reported by Demirgüç-Kunt and Detragiache (2011) and Ayadi et al. (2016). This supports our reservations regarding the problem of multicollinearity between different chapters if incorporated into a single model, which may explain the non-significant effect on bank stability reported in these studies.

Finally, the chapter results for the full sample (Islamic and conventional banks combined) resemble those reported separately for each type of bank. Specifically, our findings in Table 4, Models 17-23 continue to suggest that higher BCP compliance has a positive effect on the stability of conventional banks in Models 18-23 ( $\left[\alpha_{B C P}\right.$ chapters $]$ are positive and significant) and on the stability of Islamic banks in Models 18, 20, and 21 ( $\left[\alpha_{B C P \text { chapters }}+\alpha_{\text {inter }}\right]$, shown in Panel B, are positive and significant).

\subsection{Subsamples}

We examine the robustness of the previous results by exploring whether the relationship between BCP compliance and bank stability changes if we alter the sample composition to (i) exclude specific regions (namely the Gulf Cooperation Council [GCC], South East Asia [SEA], and the Middle East and North Africa [MENA]), (ii) exclude the United Kingdom, (iii) separately investigate listed and unlisted banks, and (iv) focus on specific periods of the economic cycle, i.e., the periods before (1999-2006), during (2007-09), and after (2010-13) the financial crisis. We also examine the effects of excluding groups of countries and banks, depending on their political stability, institutional environment, and efficiency scores.

The regional subsample results for the conventional, Islamic, and combined groups of banks are presented in Table 5, Panel A.1. We find that the association between BCP compliance and the Zscores of conventional banks is significant and positive, and that this association is robust to the exclusion of banks in the GCC region, the SEA region, and the MENA region. For Islamic banks, the association between $\mathrm{BCP}$ compliance and Z-scores is marginally positive when excluding banks in the MENA region. However, the results become insignificant when excluding Islamic banks in the GCC and the SEA regions, suggesting that the positive association is mainly driven by those two regions. Finally, the results for the full sample do not show any significant impact of BCP compliance on the stability of Islamic banks ([ $\left.\alpha_{\mathrm{BCP}}+\alpha_{\text {inter }}\right]$ in Panel A.2 is not statistically significant). 


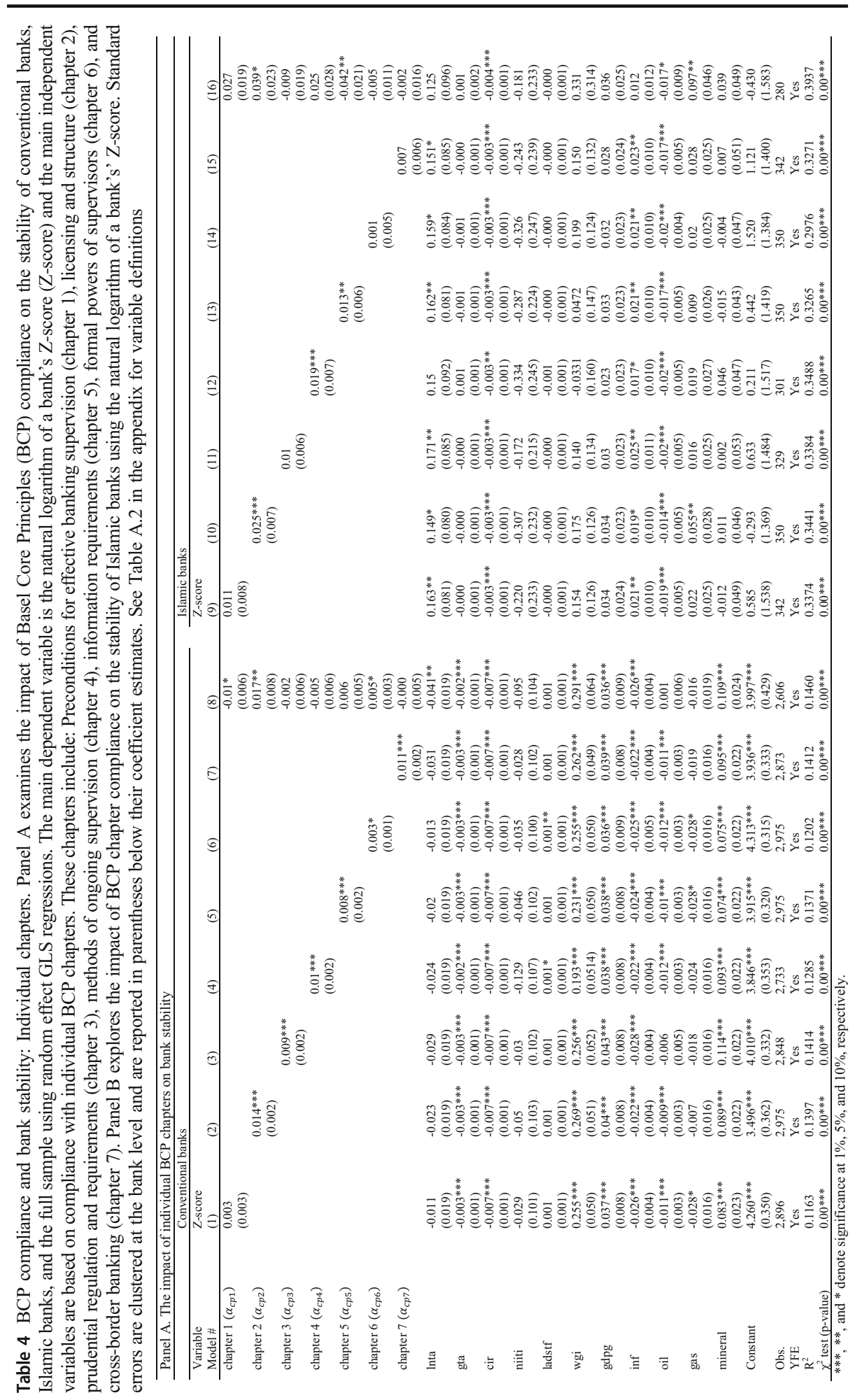


Table 4 (continued)

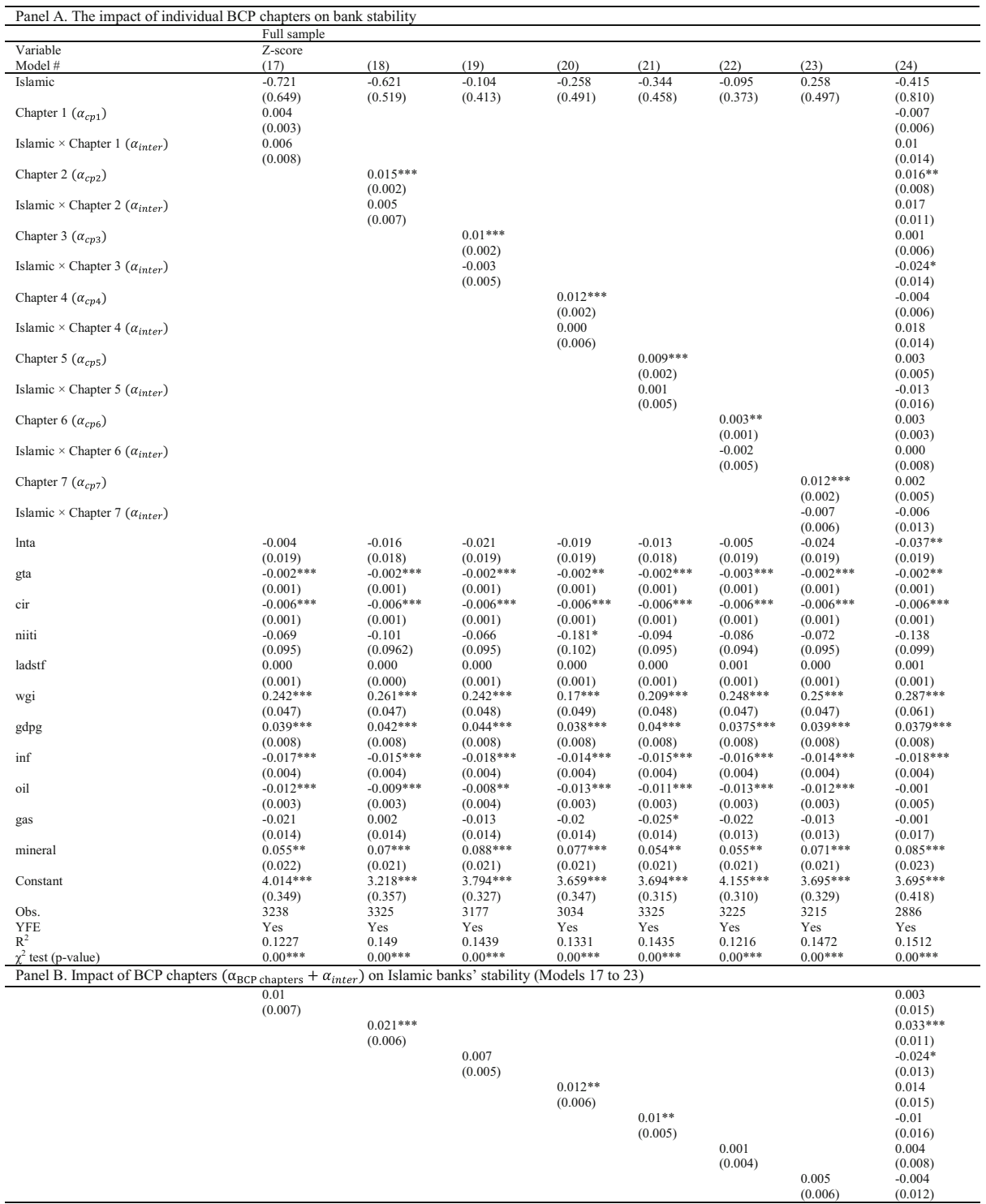

$* * *, * *$, and $*$ denote significance at $1 \%, 5 \%$, and $10 \%$, respectively.

The 167 conventional banks in the United Kingdom represent some $26 \%$ of the entire conventional bank sample. For this reason, we decided to exclude them from the analysis to examine the possibility that they might have caused a bias in the pattern of results. Table 5, Panel B.1, Models 13 show that when all UK banks are excluded, the results are positive and significant for the two bank types. In addition, Panel B.2 suggests that the effect of BCP compliance on the stability of Islamic banks is positive and significant at the $10 \%$ level when excluding Islamic banks from the UK. 


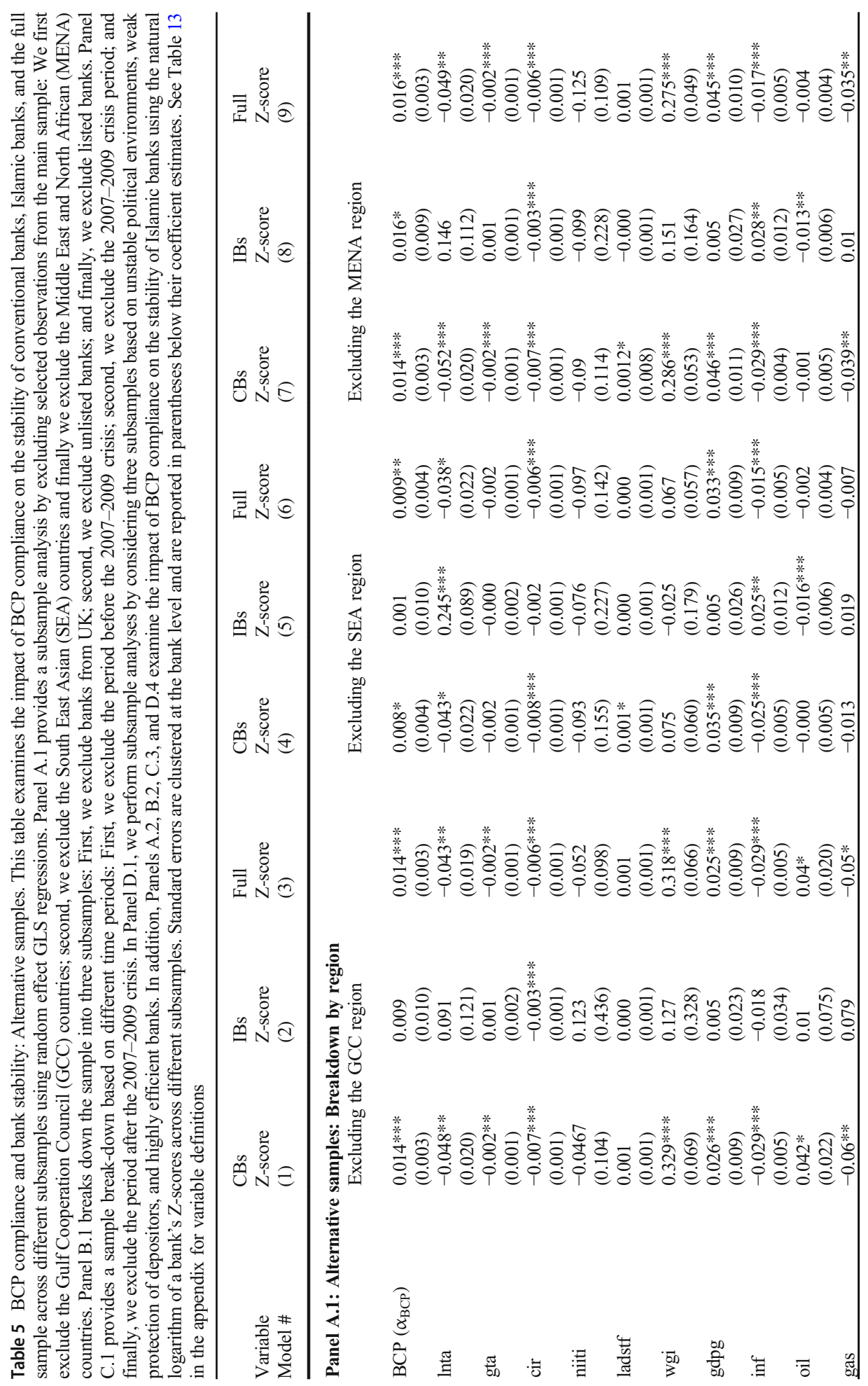




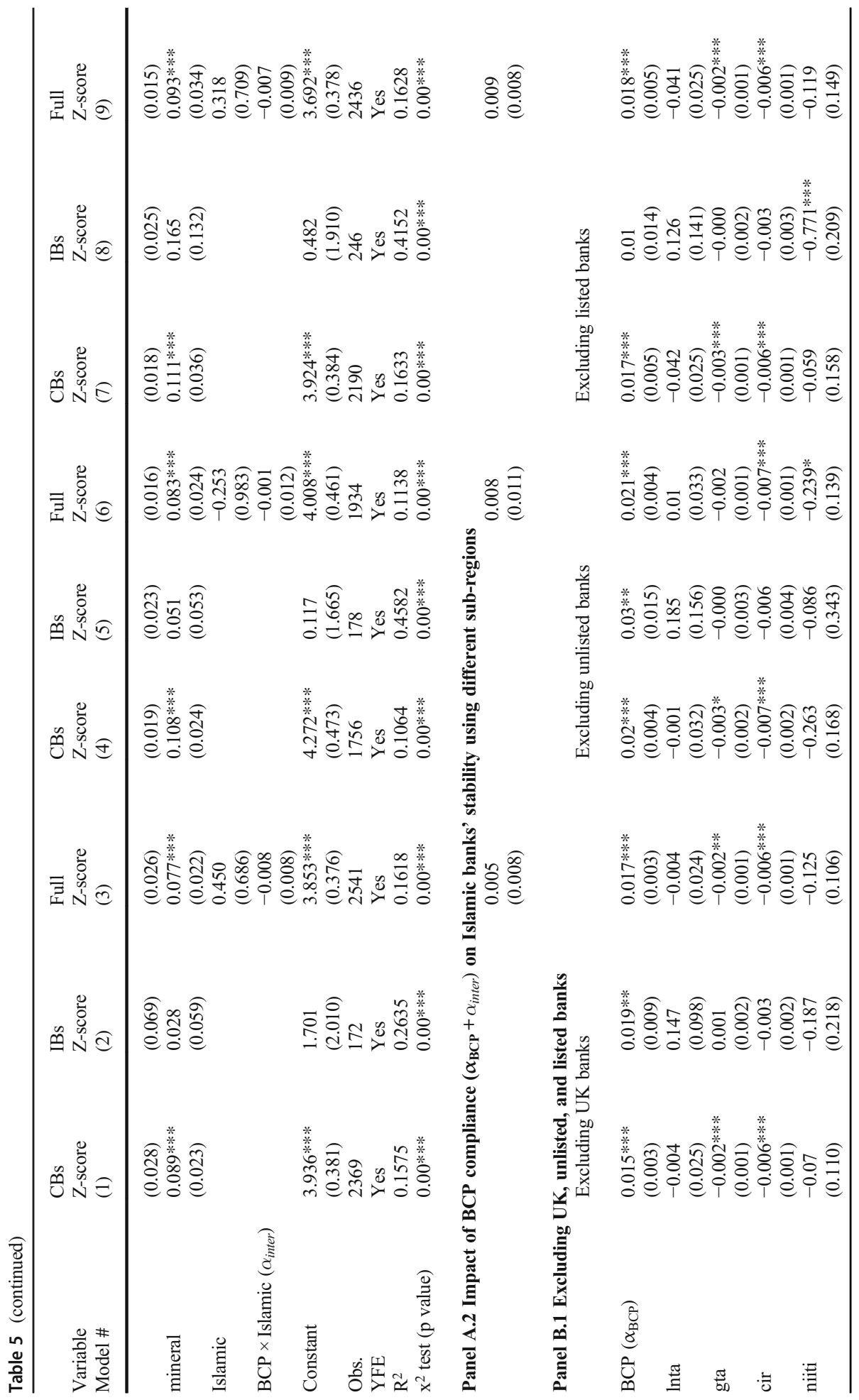




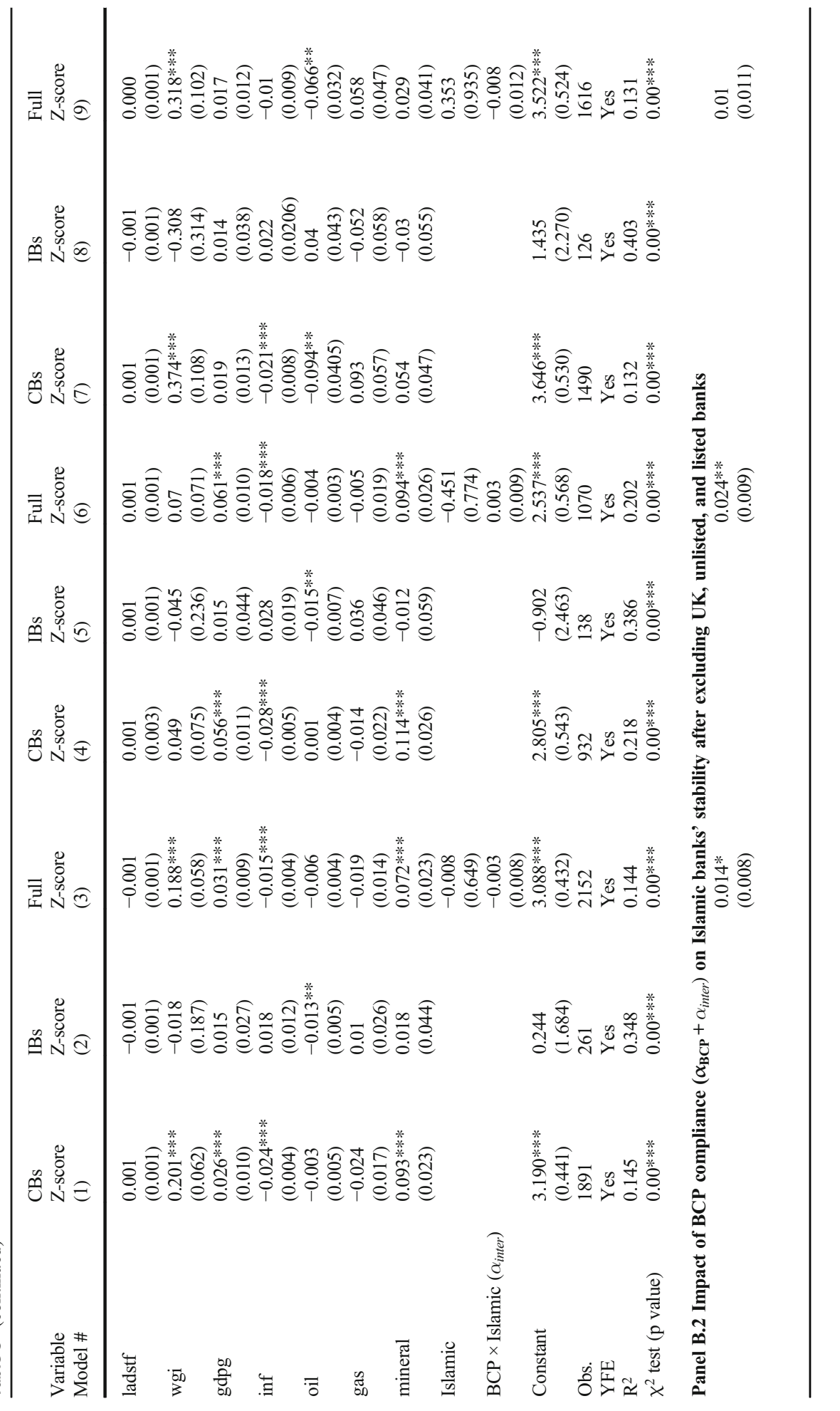

\section{Springer}




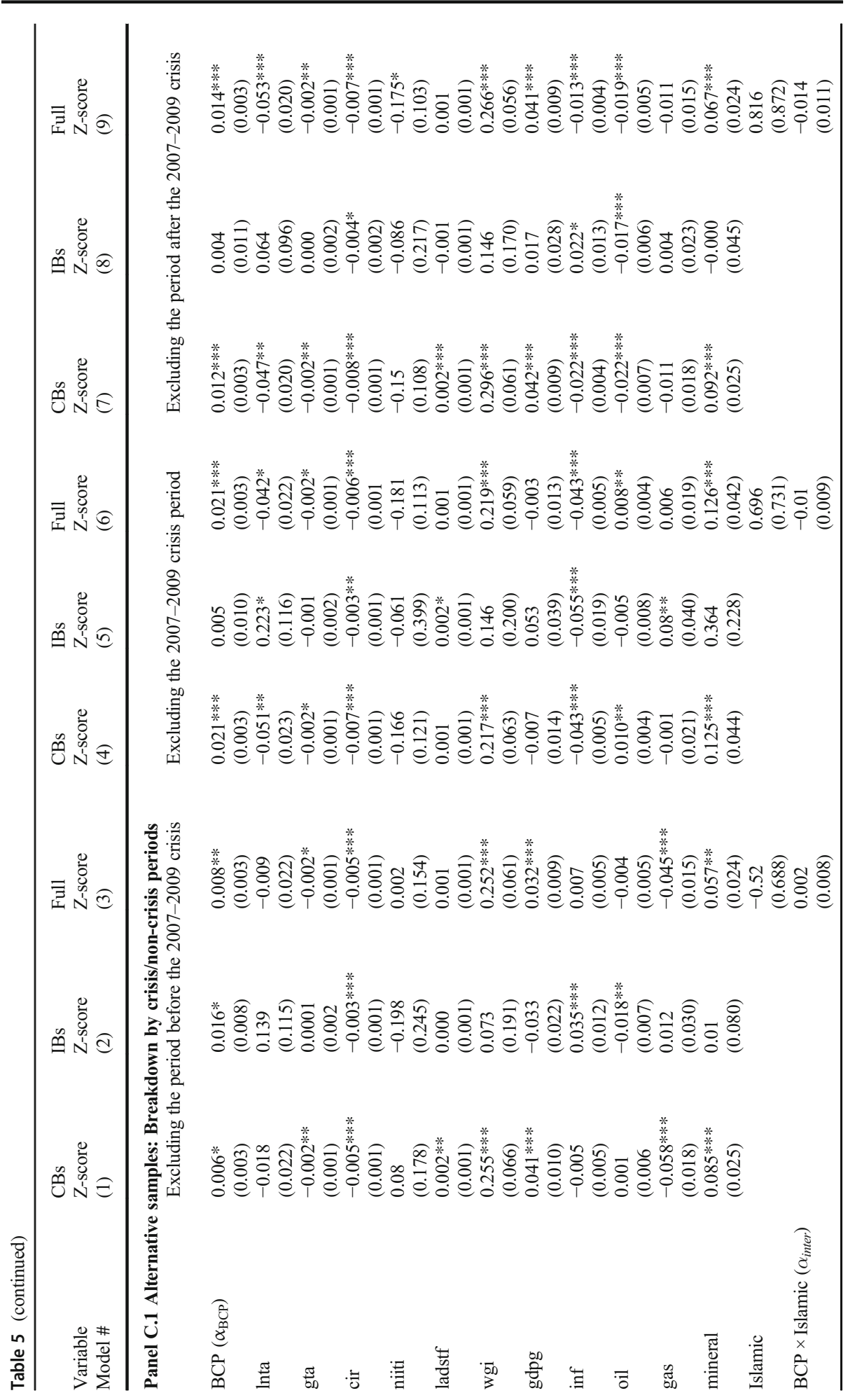




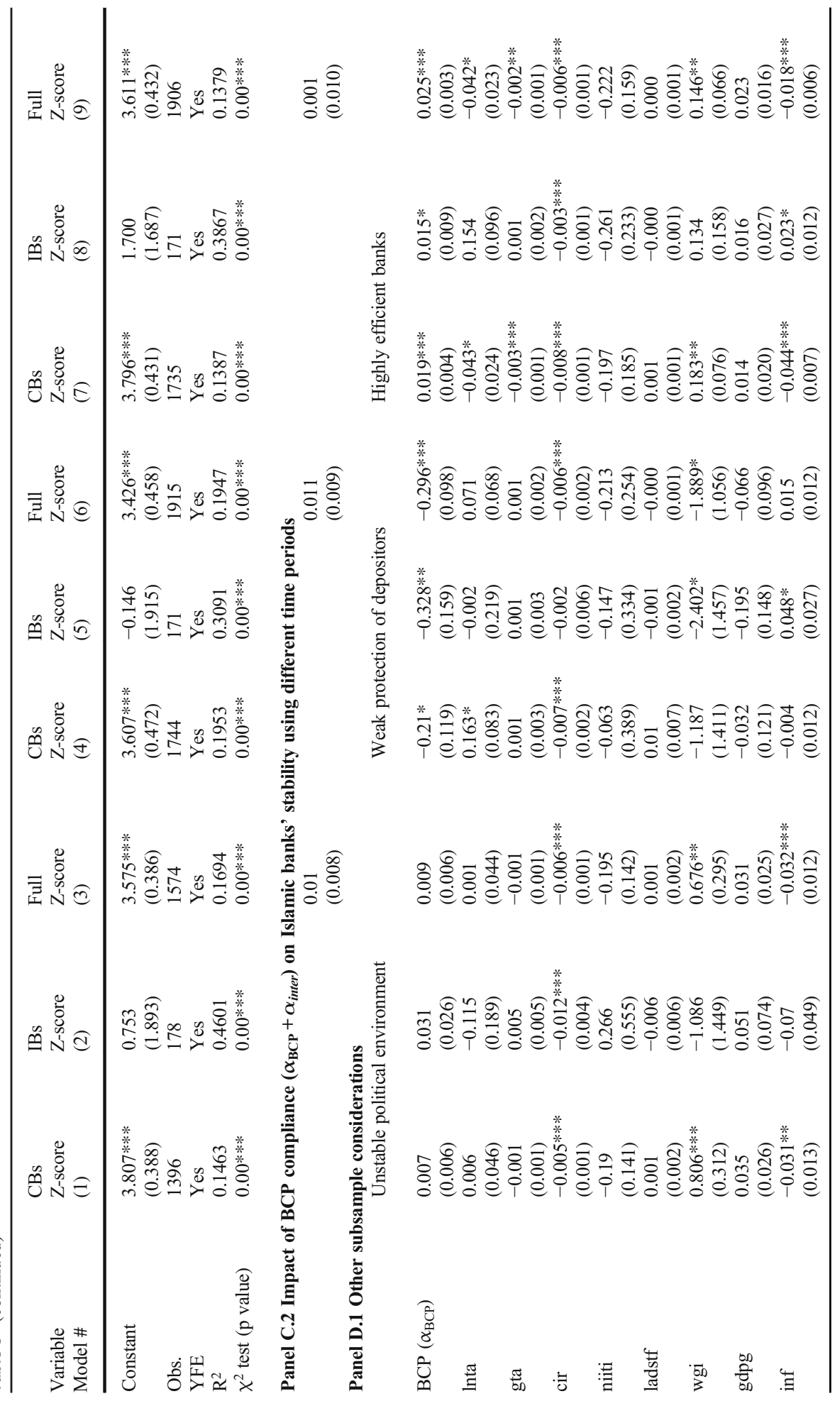




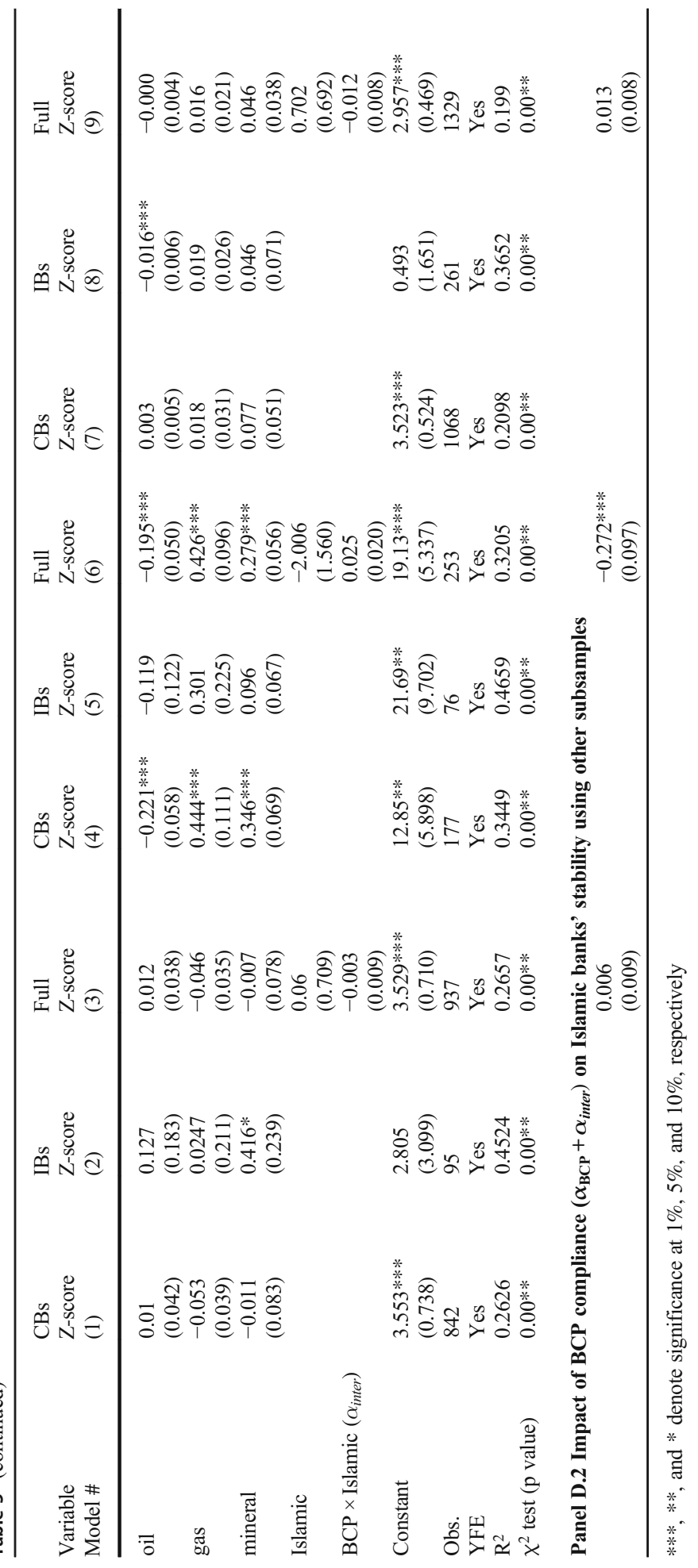


Aside from regional and country effects, the association between BCP compliance and bank stability could be mainly confined to banks that are publicly listed, due to market discipline. Listing a bank on the market implies more stringent rules and stricter capital regulation and supervision, and thus less risky behavior. In Panel B.1, Models 4-9 present the results for subsamples of listed and unlisted banks. We find clear evidence that the effect of BCP compliance on a bank's Z-score is stronger when banks are publicly listed, particularly for Islamic banks. We hypothesize that, in contrast to unlisted Islamic banks, listed banks are more likely to seek international recognition through their compliance with BCP guidelines and by holding higher capital ratios. Therefore, listed Islamic banks are more prone to market discipline and regulatory pressure than unlisted ones, which could explain the strong positive association between BCP compliance and the Z-scores. Confirming the results in Panel B.1, Panel B.2 shows that the effect of BCP compliance on the stability of Islamic banks is positive and significant at the $5 \%$ level when excluding unlisted Islamic banks.

Table 5, Panel C.1 reports the results for sub-samples classified by the economic period. The findings provide clear evidence that the association between BCP compliance and conventional banks' stability is stronger for the period that preceded the financial crisis. In other words, the estimated coefficient on BCP compliance is smallest when the period before the financial crisis is excluded from the analysis and largest when the period of the crisis itself is excluded (exclusion of the post-crisis period produces an intermediate value for the coefficient). For Islamic banks, we observe a marginally positive effect only when excluding the period before the financial crisis. Overall, although the findings continue to support a positive effect of $\mathrm{BCP}$ compliance on the stability of conventional banks and a marginally positive effect of BCP compliance on the stability of Islamic banks, it appears that compliance does not preferentially increase bank stability in periods of economic distress. One reason for this is that our sample mainly covers banks in developing countries and these banks were less affected by the financial crisis than those in developed economies. Another reason is that some countries and regions in our sample are rich in natural resources and thus less exposed to economic turmoil than other countries (Bitar et al. 2016). Finally, the results for the full sample do not show any significant impact of BCP compliance on the stability of Islamic banks $\left(\left[\alpha_{B C P}+\alpha_{\text {inter }}\right]\right.$ in Panel C.2 is not statistically significant).

We further check the robustness of our findings by studying whether the association between BCP compliance and bank Z-scores persists in countries with unstable political systems and weak institutional environments. ${ }^{8}$ In addition, we examine whether the positive effect of BCP compliance on bank stability persists for highly efficient banks. ${ }^{9}$ Table 5 , Panel D.1 indicates that BCP compliance has a negative impact on the stability of conventional and Islamic banks in countries with weak protection of depositors and an insignificant effect in countries with less stable political institutions. However, the compliance effect becomes positive and significant once again for highly efficient banks. Panel D.2 shows that the effect of the BCP compliance index on the stability of Islamic banks is also negative in countries with weak protection of depositors. Overall, these results demonstrate that compliance with $\mathrm{BCP}$ is more effective for efficient banks in countries with better institutional environments and soundly based political systems.

\footnotetext{
${ }^{8}$ We proxy for the stability of a country's political system by using an index of the durability of political institutions from the Political Regime Characteristics and Transitions of Polity IV database. We also proxy for institutional environments by using the creditor rights index from Djankov et al. (2007). We drop banks in countries with a durability index higher than the median. Likewise, we drop banks in countries with a creditor rights index that is higher than the median.

${ }^{9}$ We proxy for bank efficiency by using bank efficiency scores estimated through data envelopment analysis (DEA). We drop banks with efficiency scores that are lower than the median.
} 


\subsection{Quantile Regressions}

Next, we estimate a series of quantile regressions to investigate whether the effect of BCP compliance on bank Z-scores varies in a significant way with different stability levels. An important feature of quantile regressions ${ }^{10}$ is that they allow for heterogeneous solutions that are conditioned on the level of the dependent variable.

Table 6 reports the results for the lower (Q25), the median (Q50), and the upper (Q75) quantiles of the Z-score distribution. The results in Panel A show that the estimated coefficients for the $\mathrm{BCP}$ compliance index are positive at all quantiles for the sample of conventional banks (Models 1-3) and for the full sample (Models 7-9), but not for the sample of Islamic banks. Moreover, while the coefficients on the Z-score increase somewhat across quantiles, the Wald tests do not detect any significant differences between the coefficients for the lower quantile and the upper quantile for either bank type, nor for the combined sample. As for Islamic banks in the full sample, Panel B suggests a marginally positive effect of the BCP index on stability for the lower quantile only.

\subsection{Alternative Risk Measures}

Our previous findings consistently show a positive and pronounced effect of BCP compliance on the Z-scores for conventional banks, and a positive but less pronounced effect for Islamic banks. We now focus on whether our findings persist when we re-estimate our regressions using alternative proxies for bank stability. First, we use three different measures of bank credit risk, namely the ratio of loan loss reserves to gross loans (LLRGL), the ratio of loan loss provision to total loans (LLPTL), and the ratio of nonperforming loans to gross loans (NPLGL). These three ratios measure loan quality, with higher values indicating poorer supervision and higher credit default risk (Beck et al. 2013; Abedifar et al. 2013; Bitar et al. 2016). Second, we use the standard deviation of net interest margins (SDNIM), with higher values indicating more volatile earning margins.

The results, presented in Table 7, Panel A, show clear evidence of a negative and significant association between the BCP compliance index and the three proxies of credit risk, as well as between compliance and the SDNIM. This holds true for the sample of conventional banks in Models 1-4 and the full sample in Models 9-12, while the results for Islamic banks are only significant for the SDNIM (Model 8). Economically speaking, the estimated coefficients for the BCP index in Models 1-3 vary between 0.012 and 0.059 , indicating that a one-unit increase in the compliance index is associated with a decrease in credit risk that ranges between one percentage point (when using LLPTL) and nearly six percentage points (when using NPLGL). These results suggest that conventional banks in countries with higher BCP compliance have lower credit risk and are thus more stable.

To examine the robustness of our main finding, that BCP compliance is positively associated with the Z-score of conventional and Islamic banks, we further employ a battery of alternative estimation techniques. The results of these estimations are discussed in the following sections and confirm our key findings.

\footnotetext{
${ }^{10}$ Quantile regression results are robust to outliers and distributions with heavy tails. In addition, quantile regressions avoid the restrictive assumption that error terms are identically distributed at all points of the conditional distribution.
} 


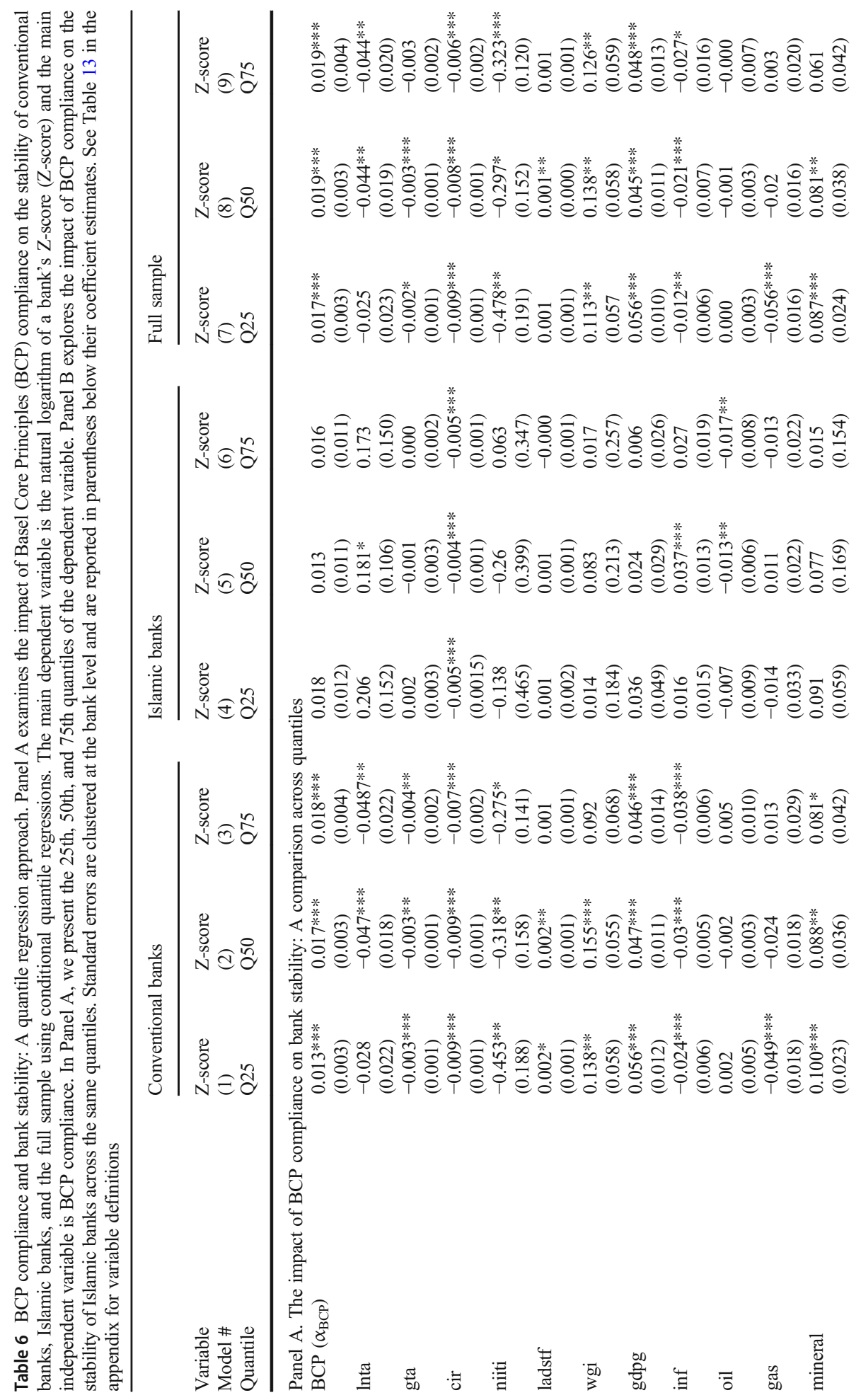




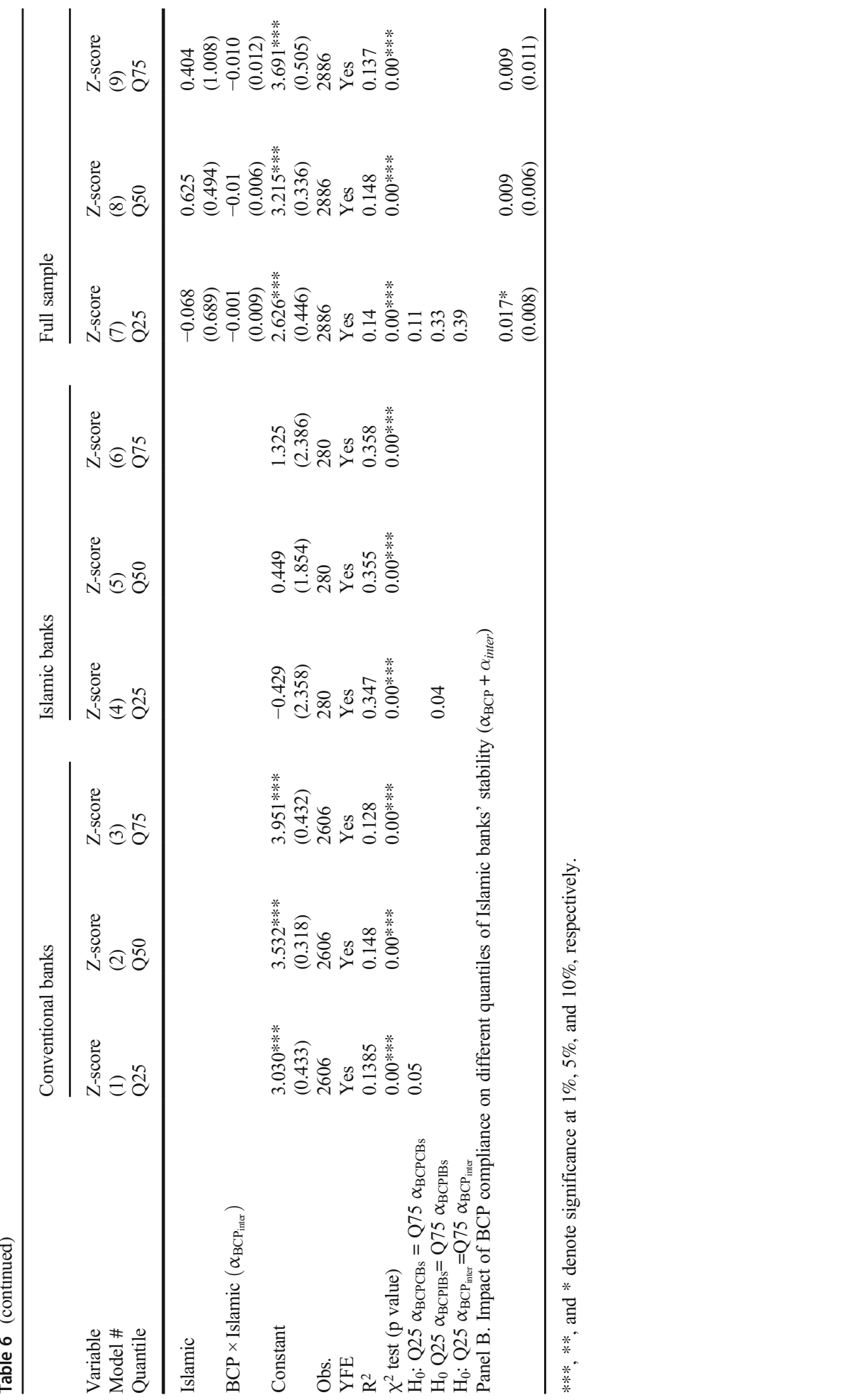




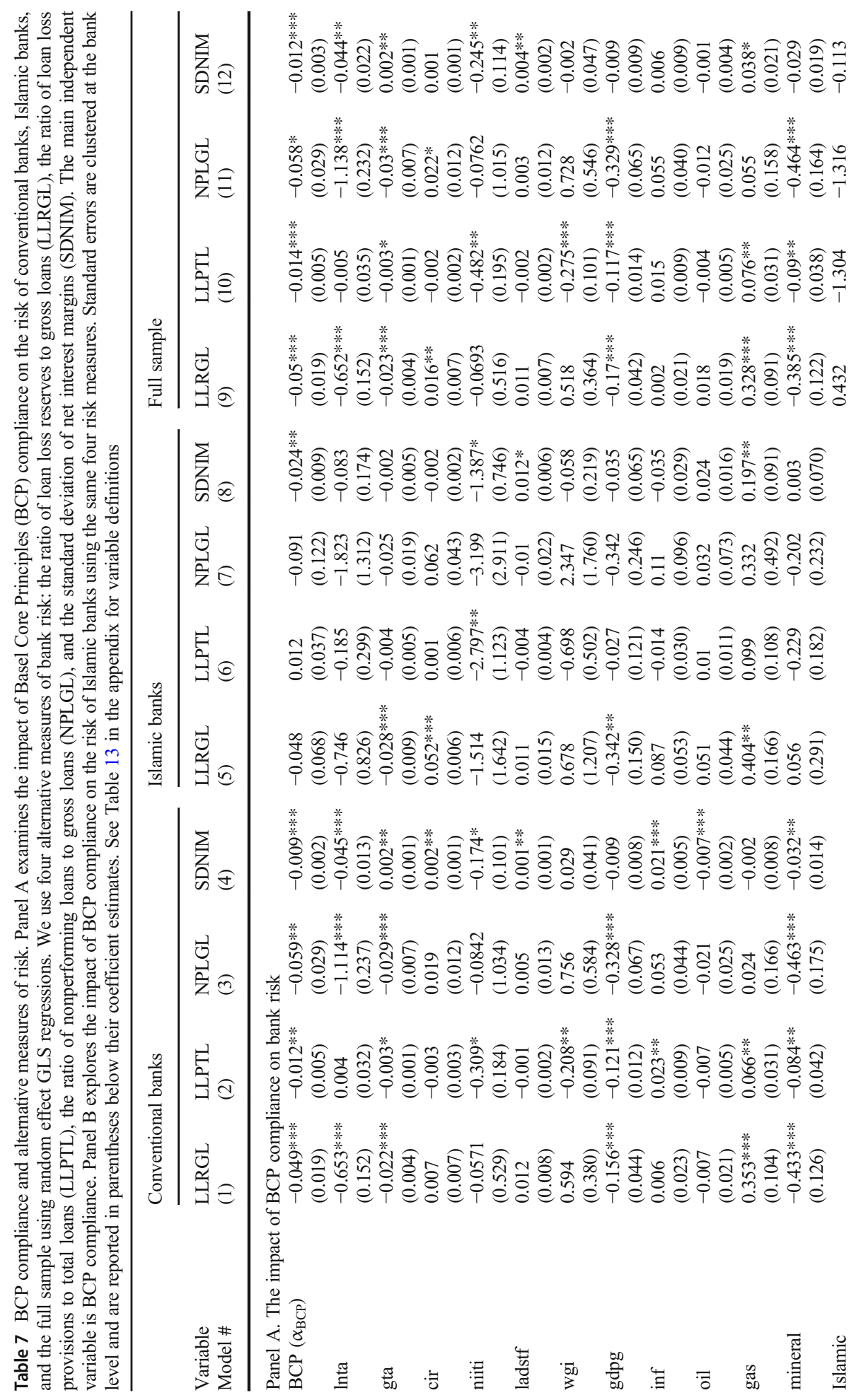




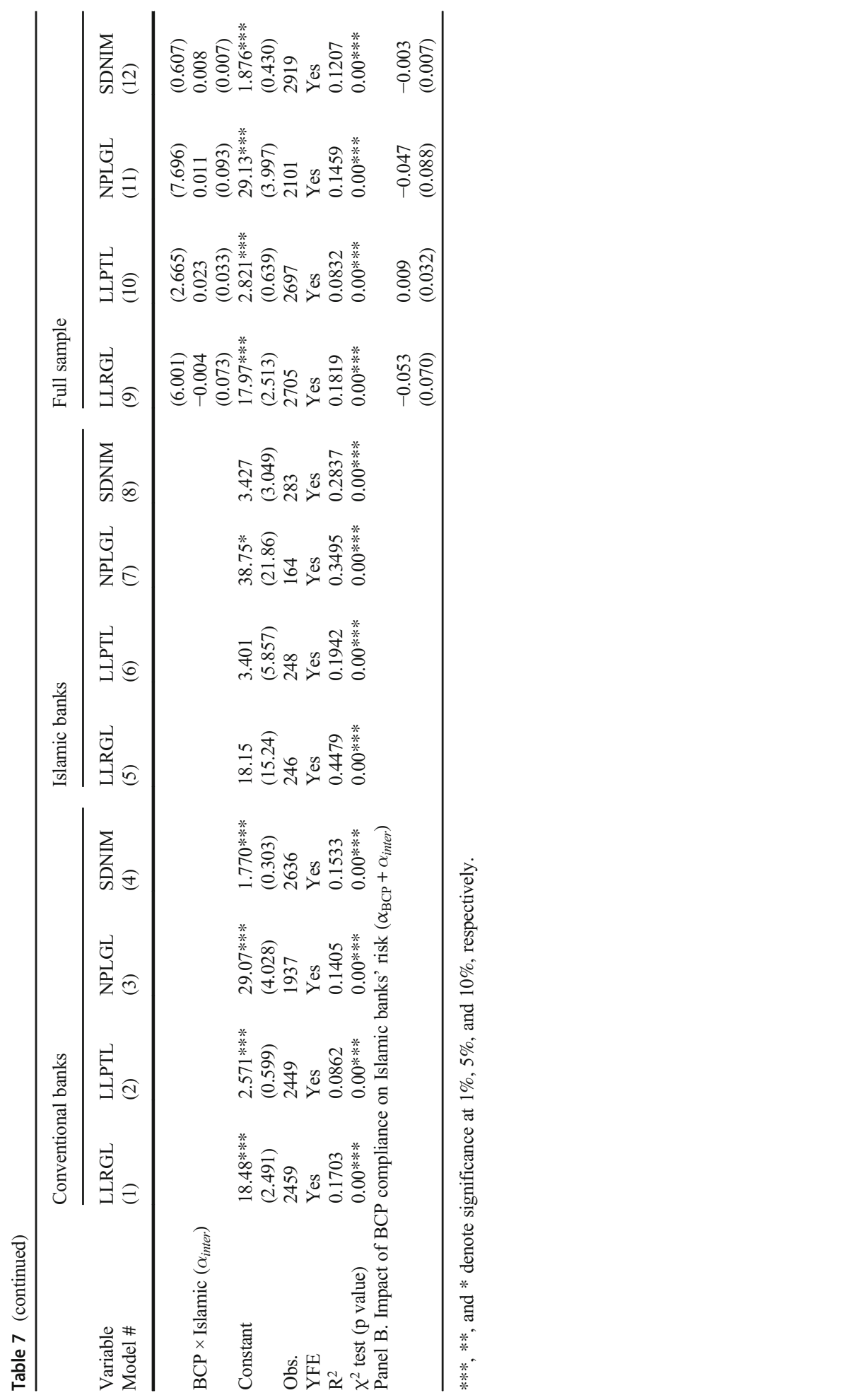




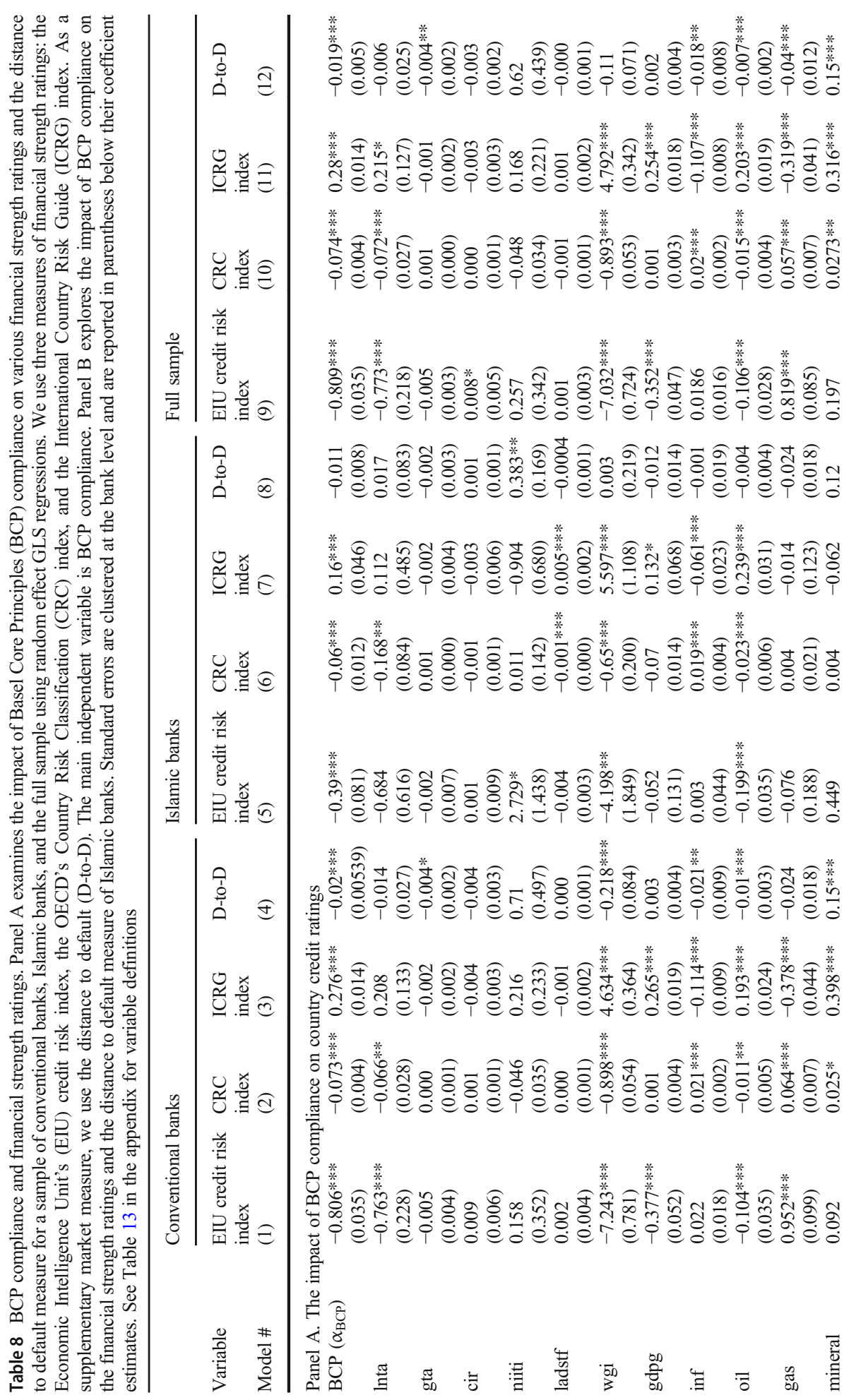




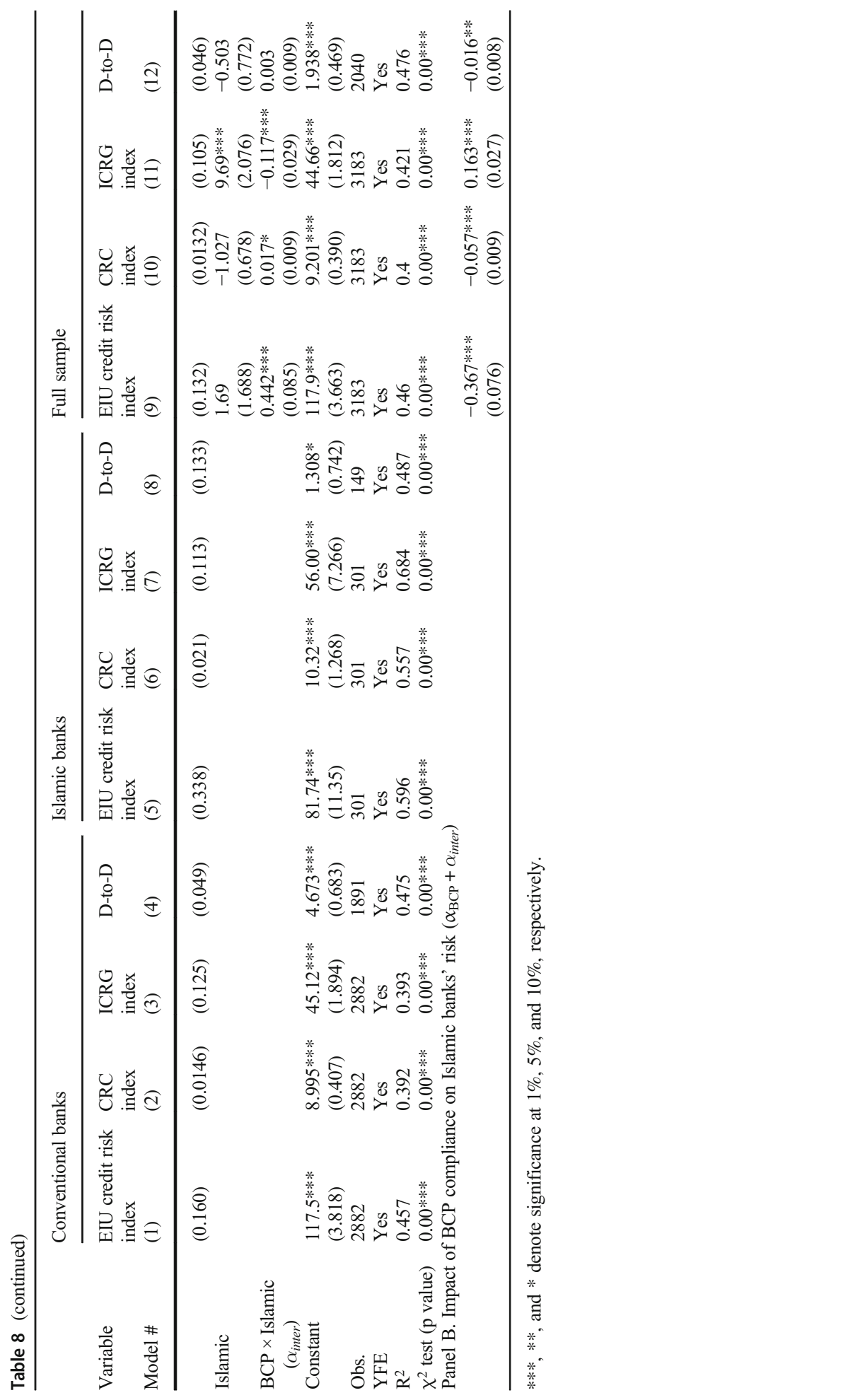




\subsection{Financial Strength Ratings and Distance-to-Default}

First, we measure financial stability using financial strength ratings. We use three independent country risk assessment methods: the Economic Intelligence Unit's (EIU) credit risk index, the OECD's Country Risk Classification (CRC) index, and the International Country Risk Guide (ICRG) index. These measures are computed based on the opinion of a global network of economists and financial analysts who have access to quantitative and qualitative information about banks and their operating environments. As a result, they should provide a more accurate assessment of a bank's overall financial stability than accounting based indicators ${ }^{11}$ For the first two credit rating measures, higher values indicate higher credit default risk, while for the third credit rating measure, higher values indicate a lower level of exposure to credit risk.

We also use the Distance to Default (D-to-D) measure developed by Moody's KMV as a measure of default risk. This index is designed to assess the likelihood of financial distress and is based on the structural approach to calculating the Expected Default Frequency (EDF). According to Moody's, default occurs when the market value of a bank's assets (i.e., the value of the ongoing business) falls below its liabilities payable (the default point). See Table 13 for detailed definitions of the financial strength ratings and the D-to-D measure and for the associated data sources.

The findings reported in Table 8, Panel A, show that the BCP compliance index is positively associated with the financial strength ratings and negatively associated with the bank D-to-D measure. This holds for all models except for Model 8, which employs distance to default as a dependent variable for Islamic banks. In addition, the findings in Panel B show that BCP compliance has a less pronounced effect on the credit rating measures of Islamic banks, compared to conventional banks (in Models 9 to 11).

\subsection{Other Estimation Techniques}

In this subsection, we examine the robustness of the results using three alternative econometric specifications and standard error estimation methods. Table 9, Panel A provides the results of regressing the BCP index on banks' Z-scores. First, we use truncated regressions to address any biases related to the upper and lower tails of the distribution of observations for the dependent variable. In the second estimation, we use bootstrapped standard errors from 100 random resamples of the two bank types employed in the sample. In the third estimation, we correct for heteroscedasticity by using the White procedure. Importantly, the estimated coefficients of the BCP index are significant and positive in all models, except for Model 4 which applies truncated regressions to Islamic banks. The findings in Panel B further suggest that BCP compliance has a significant, positive effect on the Zscores of Islamic banks at the $1 \%$ level (in Models 8 and 9).

\subsection{Propensity Score Matching}

Next, we employ the Propensity Score Matching (PSM) technique proposed by Rosenbaum and Rubin (1983) to verify the robustness of our results. PSM consists of matching bank observations based on the probability of increasing the country's BCP compliance index.

\footnotetext{
${ }^{11}$ Recent papers also used risk assessment provided by rating agencies as an alternative measure of financial stability. For instance, Vazquez and Federico (2015) use Moody's bank risk categories as an alternative risk measure to bank Z-score. Their findings show that credit ratings by rating agencies are important predictors of bank failure.
} 


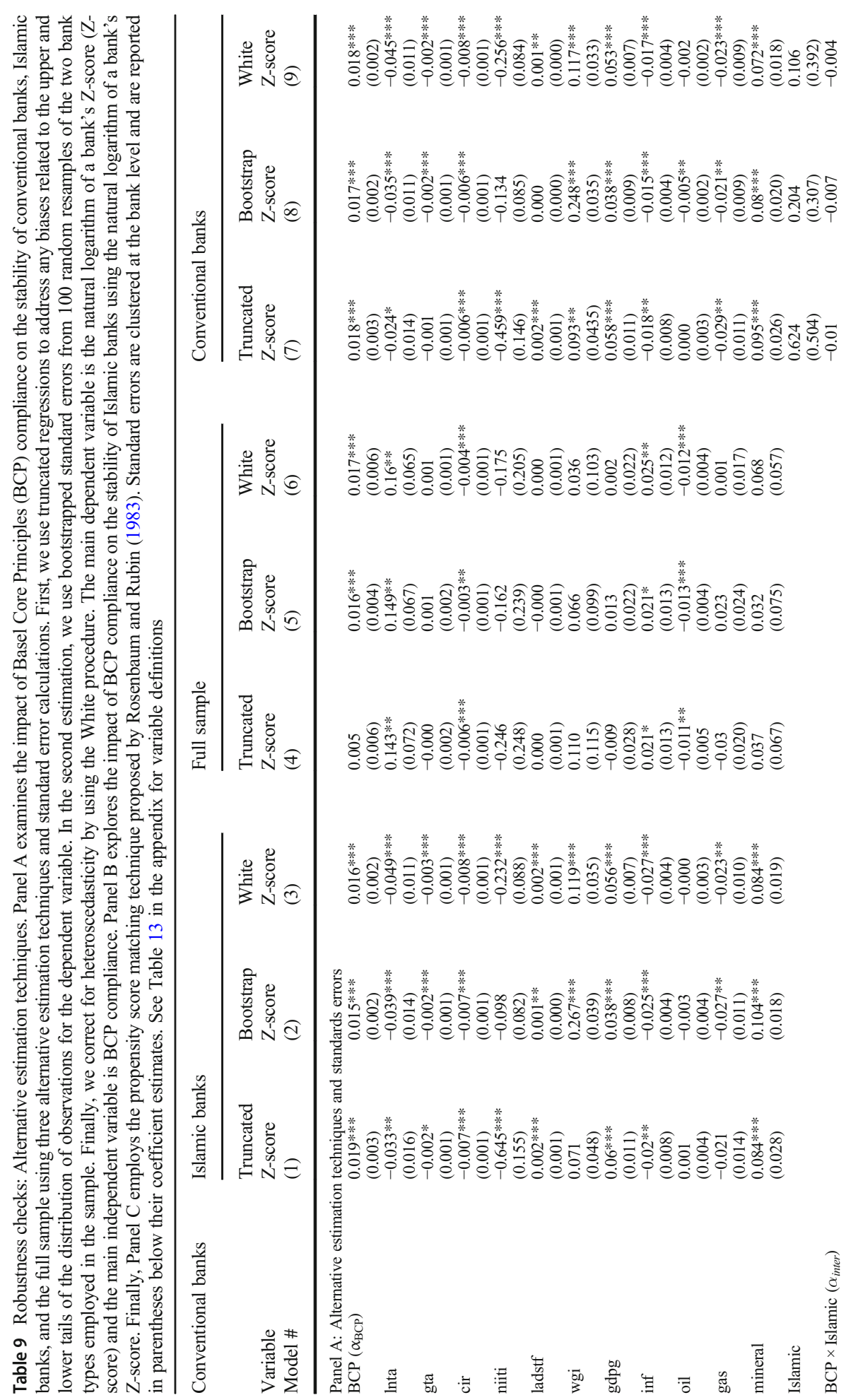




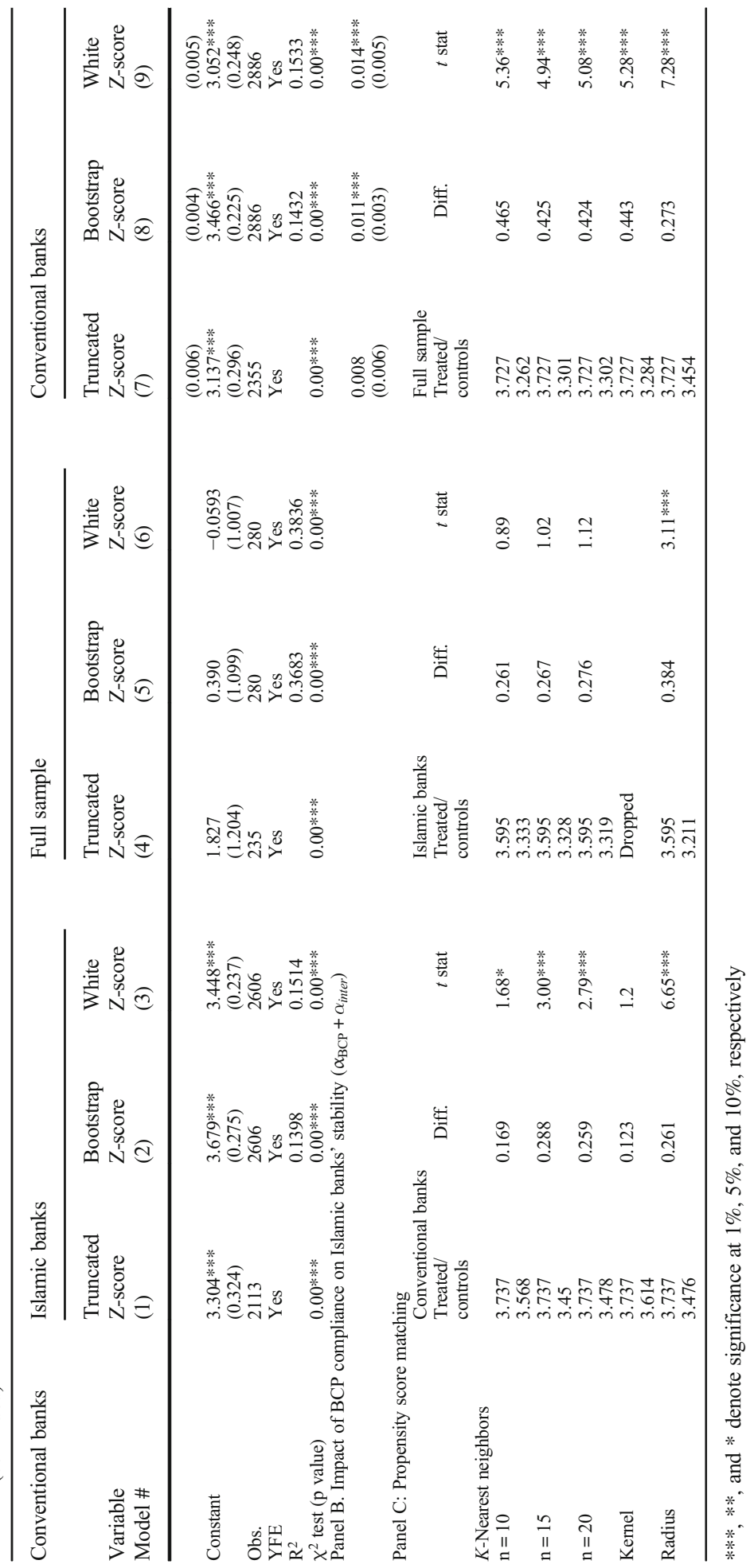

\section{Springer}


To implement PSM, we create a BCP compliance dummy variable that takes on a value of one if a country's BCP compliance index has a value greater than or equal to the median, and zero otherwise. We then estimate a logit model where we regress the $\mathrm{BCP}$ compliance dummy on all control variables in the baseline model and the year fixed effects. We use the estimated scores to produce matched observations between countries with higher and lower values of BCP compliance. Additionally, we employ three different matching methods: K-nearest neighbors (with $n=10, n=15$, and $n=20$ nearest neighbors), Gaussian kernel matching, and radius matching. In the matched samples (presented in Table 9, Panel C), we continue to find evidence that conventional banks in countries with higher BCP compliance have higher $\mathrm{Z}$-scores than matched conventional banks in countries with lower BCP compliance. We obtain very similar results for banks in the full sample, but the effect is less pronounced for the sample of Islamic banks. For each matching method, we report $t$ statistics for the differences between the treated countries, with high BCP compliance, and the countries with low BCP compliance in the control group. For BCP compliance, the natural logarithm of the Z-score differences between the treated and control groups vary between 0.123 and $0.288 \%$ for conventional banks, between 0.123 and $0.276 \%$ for Islamic banks, and between 0.273 and $0.465 \%$ for the full sample. These differences are statistically significant at the $1 \%$ level in almost all models, except for the differences in the sample of Islamic banks, which are only significant when using the radius matching method.

\subsection{Additional Control Variables}

In this subsection, we address the issue of potential omitted variables. Thus, in addition to bank level, macroeconomic and institutional control variables, we include a series of four financial market regulation control variables to further check the robustness of the results.

Following Bitar and Tarazi (2019), we include the concentration ratio (Concentration), calculated as the ratio of the assets of the three largest banks to the total assets of the banking sector in the country. ${ }^{12}$ Second, based on the World Bank's surveys on Banking Regulation and Supervision database, ${ }^{13}$ we use two market regulatory measures: market discipline and private monitoring (Market discipline) and entry requirements (Bank entry). The first measure captures the degree to which banks are required to disclose accurate information to the public and whether there are incentives to increase market discipline and private monitoring. The second measure controls for entry restrictions in terms of obtaining a banking license. Finally, we use the Heritage Foundation's financial freedom index (Financial freedom) to measure the extent of financial and capital market development as well as the openness to foreign competition (Bitar et al. 2018).

The findings are consistent with our previous results. As Table 10 shows, the explanatory variable (the $\mathrm{BCP}$ index) and the control variables maintain their signs and significance as before. As regards the financial market variables, we find that market discipline and private monitoring, entry requirements, and financial freedom have a positive and statistically significant effect on the stability of conventional banks, while the same effect appears to be absent for Islamic banks. In addition, concentration reduces bank stability. These findings suggest that the better the institutional

\footnotetext{
$\overline{12}$ We also use C5 and recompute $\mathrm{C} 3$ and $\mathrm{C} 5$ according to the share of bank deposits. The results remain highly robust.

${ }^{13}$ This information is collected based on surveys performed by the World Bank.
} 


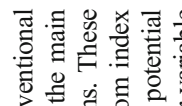

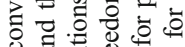
范 不 政

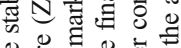

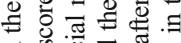

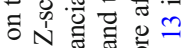
8 a w

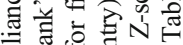

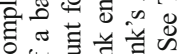
ठ․ जि

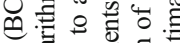
पु 50 品 응을 西 喝

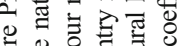
응을 흘 드. 응 o

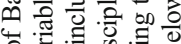

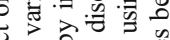
递

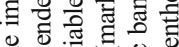

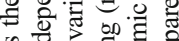
s 흠 ×

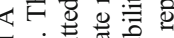
ब ¿ 更 o 更证。:

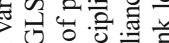
음

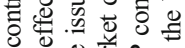
可

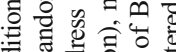

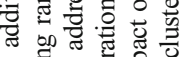

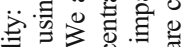
屡

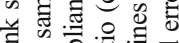

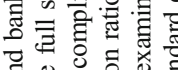

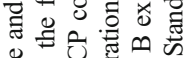

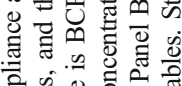
鱼 o ․ㅠ. 웅.

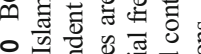

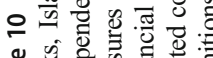

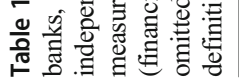

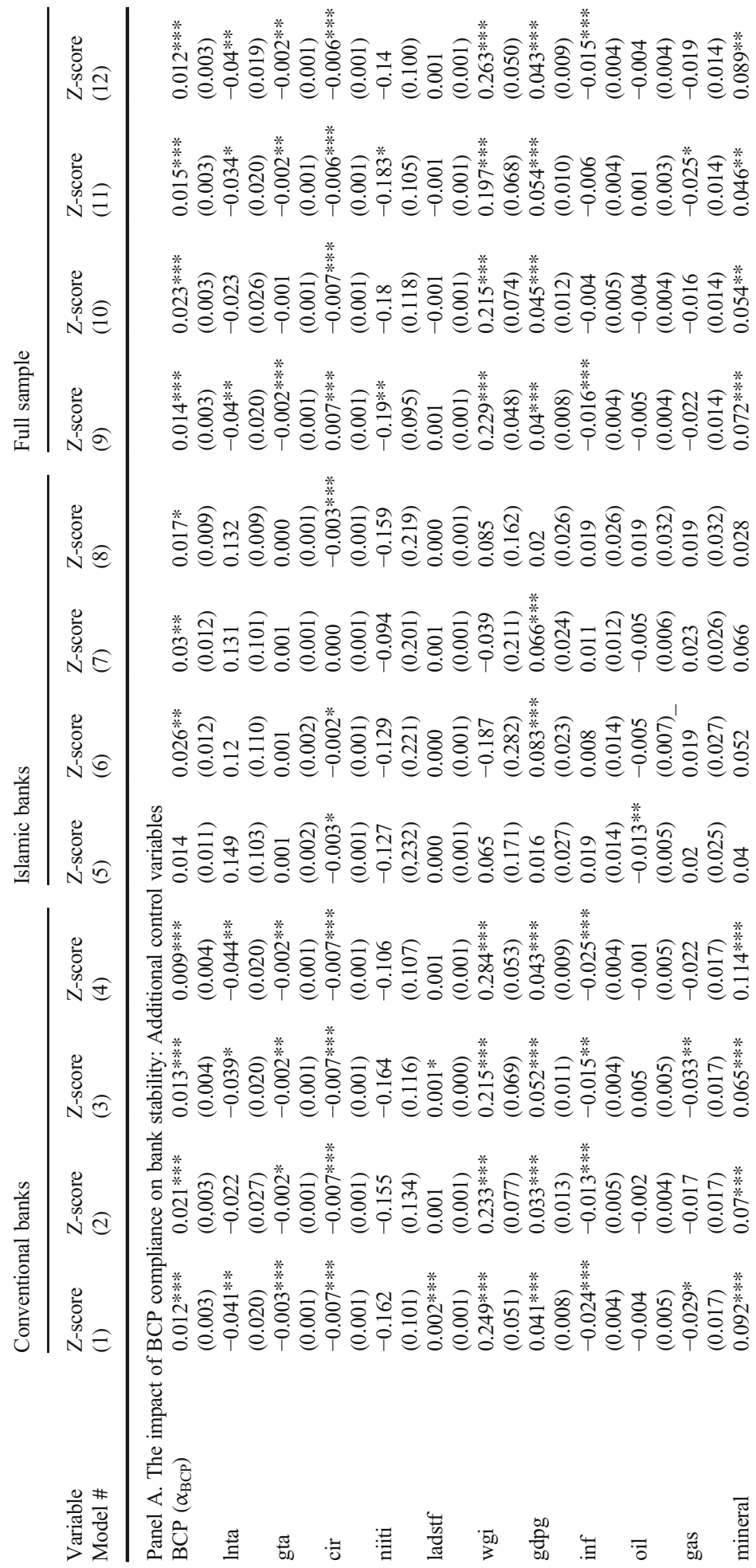




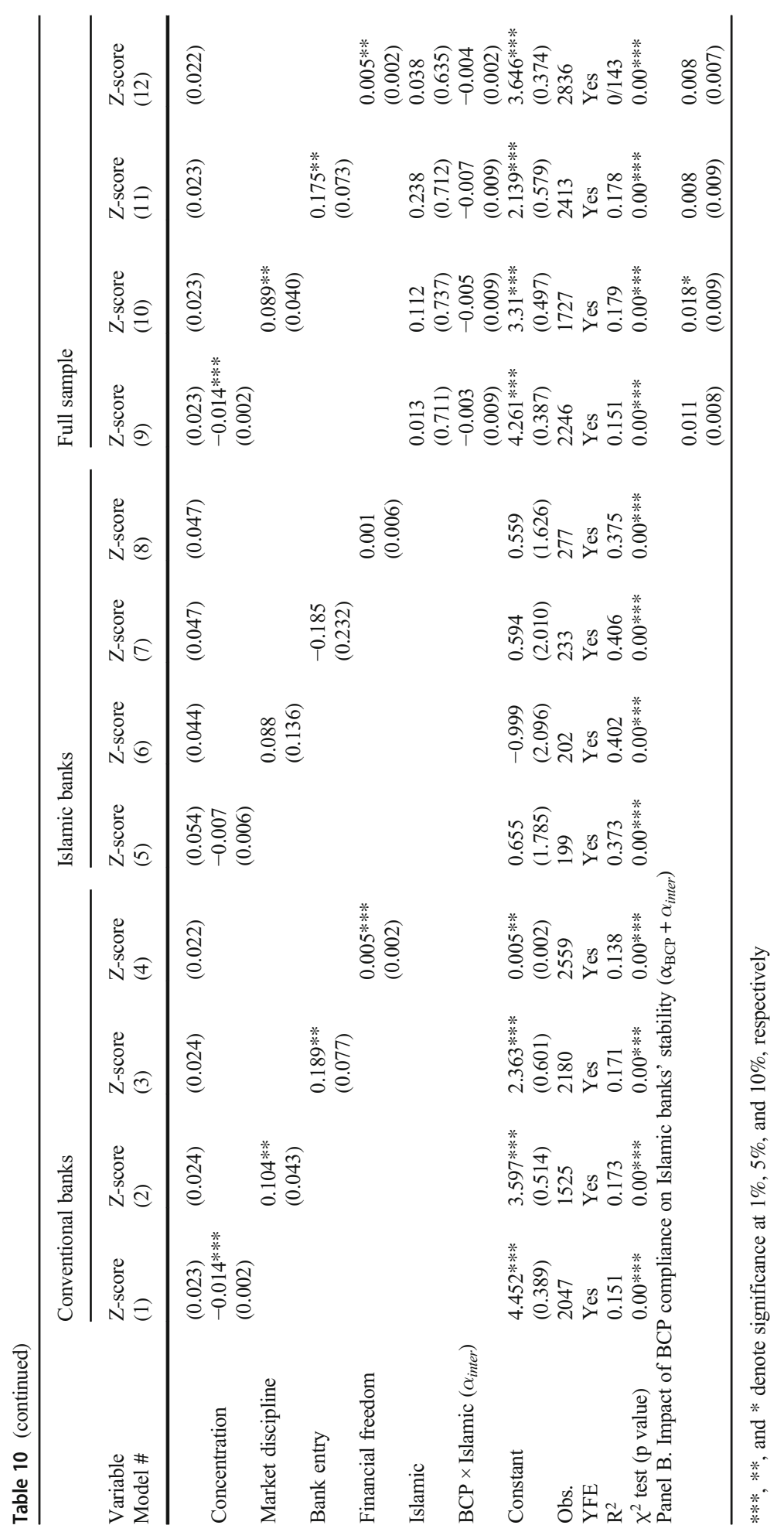




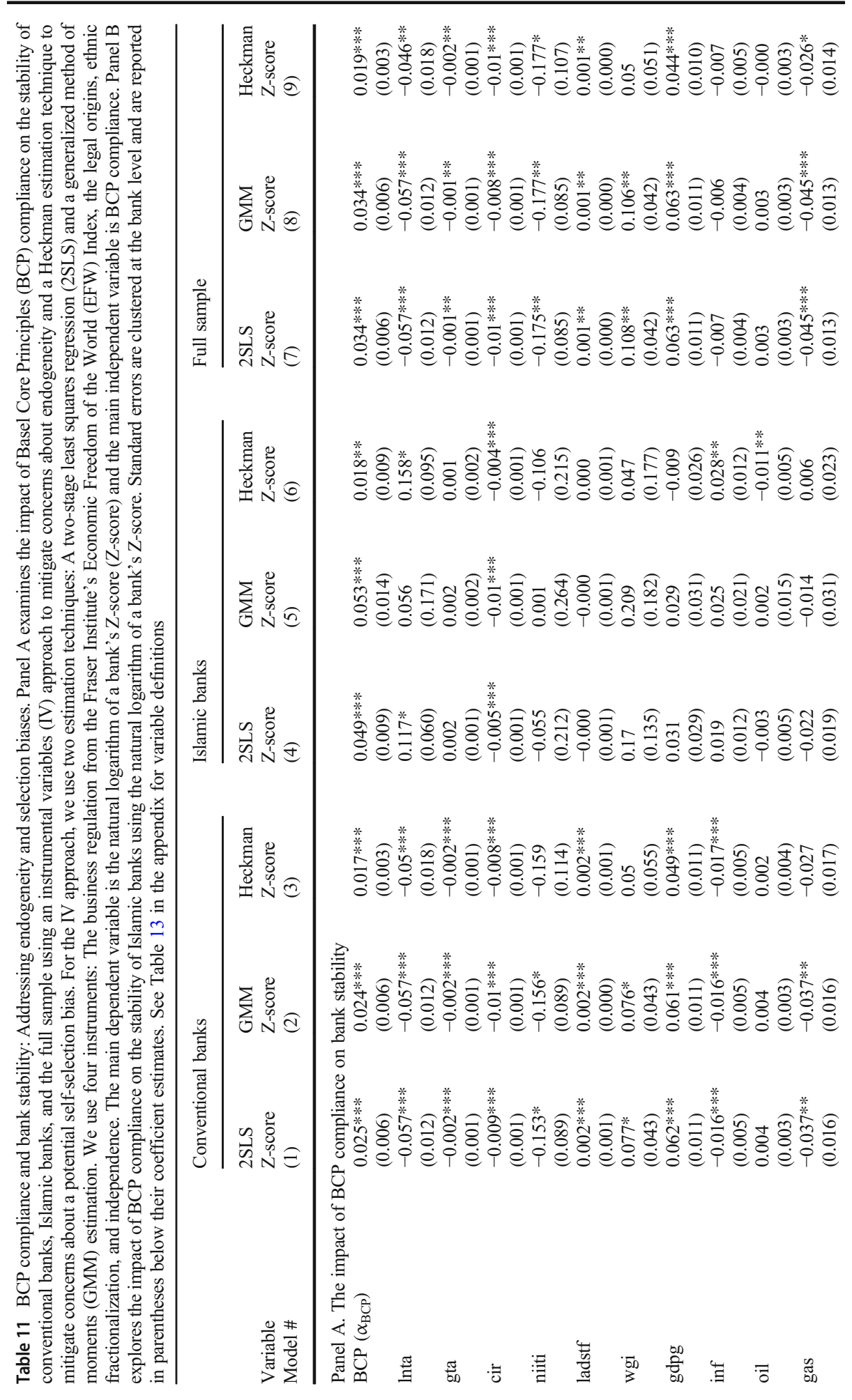

\section{Springer}




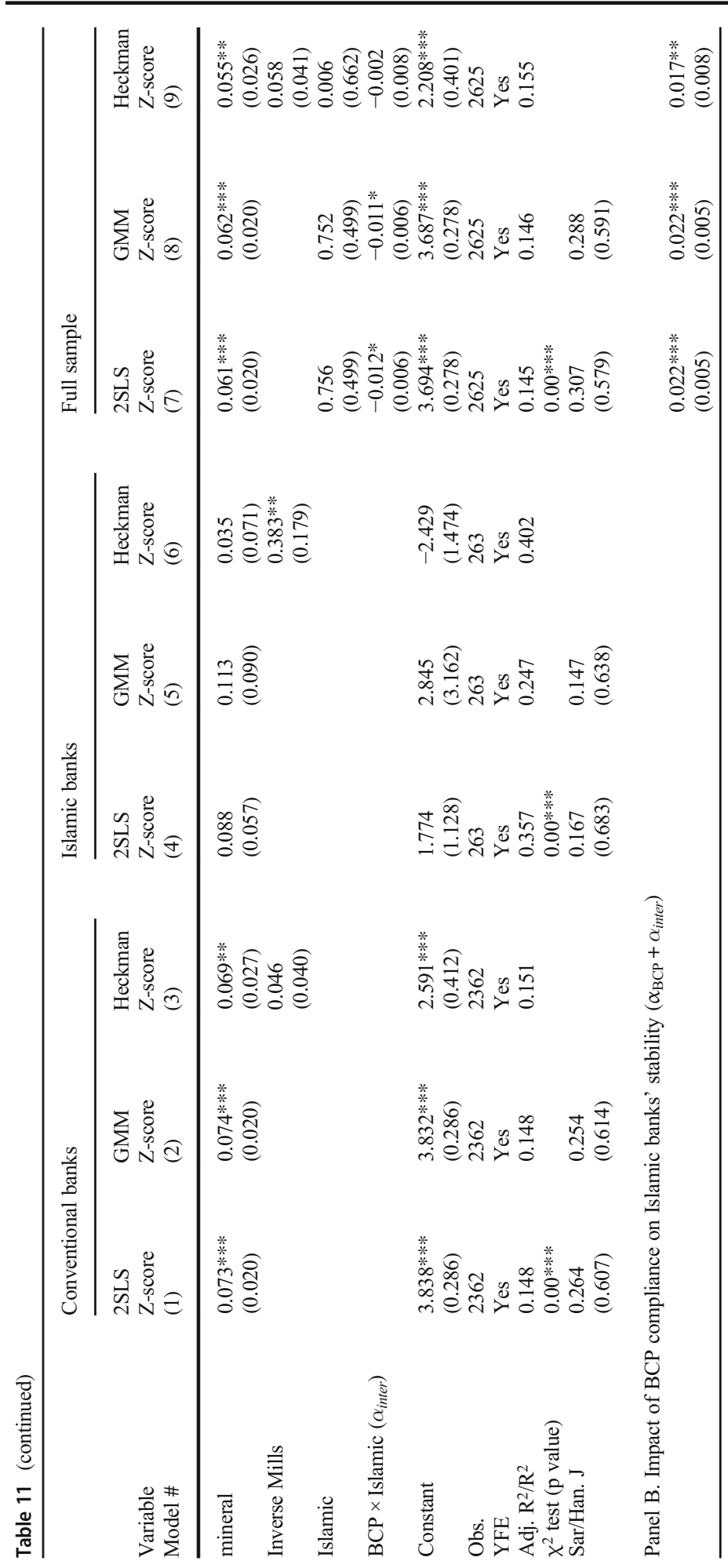


environment (i.e., superior financial market regulation and increased competition), the more conducive the situation is to banking stability.

\subsection{Addressing Endogeneity and Selection Biases}

A country's BCP index could be endogenous, reflecting the impact of some omitted variables (e.g., market concentration, market regulation, financial freedom) or the impact of reverse causality. The findings in the previous sections demonstrate that the results are robust to the inclusion of additional control variables. Thus, we now address concerns about reverse causality. A common undertaking in the literature (e.g., Barth et al. 2013; Bitar and Tarazi 2019 ) is to address endogeneity by employing the Instrumental Variables (IV) approach. Thus, we use this approach and select four instruments chosen on the basis of the existing literature on law and finance (Beck et al. 2003; Barth et al. 2009; Barth et al. 2013; Öztekin 2015). These studies argue that legal origins and business regulation have important effects on banking regulation and are exogenous. However, a potential concern with using these two instruments is that they might affect bank capital decisions through channels other than the $\mathrm{BCP}$ index. We use two approaches to address this issue. Firstly, rather than employing legal origins and business regulation by themselves as instruments, we employ them along with two additional instruments: ethnic fractionalization and the $(\log )$ number of years that the country has been independent. The literature shows that these two instruments are less likely to have a direct impact on bank capital stability or some other omitted variable (Öztekin 2015). Additionally, while we instrument for the country's BCP index with legal origins and business regulation (along with ethnic fractionalization and independence), we control for the legal origins and business regulation in the second-stage regression.

The results are reported in Table 11, Models 1 and 2 for conventional banks, Models 4 and 5 for Islamic banks, and Models 7 and 8 for the full sample. We use two estimation techniques, a two-stage least squares regression (2SLS) and a generalized method of moments (GMM) estimation. The results provide clear evidence of a positive and significant association (at the $1 \%$ level) between the BCP compliance index and the Z-score in all models. For the full sample, the results in Panels A and B suggest that BCP compliance has a positive and significant effect on the stability of conventional banks ( $\alpha_{B C P}$ is positive and significant). The same effect is observed in the case of Islamic banks $\left(\left[\alpha_{B C P}+\alpha_{\text {inter }}\right]\right.$ is positive and significant), but it is less pronounced.

In addition, we use a Heckman (1979) selection approach to mitigate concerns about a potential self-selection bias. The main objective of this technique is to correct for a selfselection bias based on whether or not countries are highly compliant with the Basel Core Principles. As a first step we define a dummy variable that takes on a value of one if the value of a country's BCP compliance index is greater than or equal to the median, and zero otherwise. We then estimate a probit model that regresses the dummy variable on the two instruments used before (i.e., rule of law and business regulation), as well as on the bank- and country-level control variables and the year-fixed effect from the baseline model. In the second-stage regression, we consider the natural logarithm of the Z-score as the dependent variable, the BCP compliance index as the independent variable (in addition to the same control variables), and the self-selection parameter (measured as the inverse Mills ratio) estimated from the first-stage regression. The findings of the second-stage regression (presented in Table 11, Panels A and B, Models 5, 10, and 15) continue to suggest that both conventional and Islamic banks are more stable in countries with a higher $\mathrm{BCP}$ compliance index. 


\section{Concluding Remarks}

While previous studies that used the BCP index found no evidence of a significant association with bank stability and efficiency, this study suggests a positive effect of BCP compliance on the stability of banks in 19 countries. The findings are robust when the effects are examined separately for individual chapters of the BCPs. The association between compliance and stability is more pronounced for conventional than for Islamic banks. A deeper investigation into the components of the dependent variable (the Z-score) shows that the impact of compliance is confined mainly to the capital ratios of the two bank types.

Our findings have important implications from a regulatory perspective. Because compliance with the BCPs is effective in improving the stability of Islamic banks, it is likely that compliance with the CPFIRs can also positively affect Islamic bank stability, as they are modelled closely on the BCPs. Our findings persist across a battery of robustness checks that address potentially omitted variables, endogeneity concerns, and selection biases, and which also employ alternative estimation techniques. This first empirical assessment of Islamic banks shows that the BCPs are less effective at increasing the stability of Islamic banks than conventional banks. This difference leaves the open question of whether BCP standards should be amended to accommodate some of the specificities of Islamic banks, rather than having two separate sets of guidelines. One argument in support of a unified set of regulations is that it would lead to a more stable financial system in countries where the two bank types operate in tandem.

It is worth noting that the import of our results depend largely on the sample size, the choice of countries, and the validity of the accounting measures used as proxies for bank stability. Whilst increasing the sample size is beyond the potential of our study, since it would require additional surveys by the IMF and the World Bank, we attempt to overcome potential limitations related to measurement errors by using a wide range of proxies and econometric techniques. A next step in our analysis would be to explore the effect of the CPIFRs on the stability of Islamic banks and to compare it with the effect of the BCPs. In addition, it would be important to identify which BCP and CPIFR chapters are responsible for any significant effect on bank stability; in this context, the CPIFR chapters that reflect the specificities of Islamic banks will warrant particular attention. Unfortunately, data allowing for a comparative assessment of the two sets of guidelines are not currently available but will hopefully be incorporated into future research on this topic. Similarly, one could attempt to investigate whether the BCP and CPIFR guidelines have the same effect on Islamic bank efficiency by employing scores derived from nonparametric approaches or by using additional market-based data on stock returns and Tobin's Q, for instance. While the IFSB has asked banks to start reporting their data on the CPIFRs as of January 2016, the data are unlikely to be available before the end of 2018, which corresponds to a period outside the scope of this paper.

Acknowledgments We would like to thank participants at the 2018 Financial Engineering and Banking Society (FEBS), the MBF International Rome Conference on Money, Banking, and Finance and participants at the 34th French Finance Association Conference (Valence, France), Amine Tarazi (University of Limoges), Laurent Weill (University of Strasbourg), Anna Maripuu for collectiong data on financial strength ratings, Gabriela Maciel (RES), and Abdullah Haron (MCM) for their comments on an earlier version of our paper; Stephanie Fallas for editorial assistance; Jennifer Azar for administrative assistance. All errors and omissions are our own. 


\section{Appendix}

Table 12 Comparison between BCP chapters and CPIFR chapters

\begin{tabular}{ll}
\hline Organization & $\begin{array}{l}\text { IMF and World Bank Basel Core Principles } \\
\text { (BCPs) }\end{array}$ \\
Program & $\begin{array}{l}\text { Basel Core Financial Sector Assessment } \\
\text { Program (FSAP) }\end{array}$ \\
Starting date & $\begin{array}{l}\text { 1999 } \\
\text { Objective }\end{array}$ \\
& $\begin{array}{l}\text { To promote the stability and soundness of the } \\
\text { financial sector, and to assess its potential } \\
\text { contribution to growth and development. }\end{array}$
\end{tabular}

Principle 1 Objectives, independence, powers, and transparency

Principle 2 Permissible activities

Principle 3 Licensing criteria

Principle 4 Transfer of significant ownership

Principle 5 Major acquisitions

Principle 6 Capital adequacy

Principle 7 Risk management process

Principle 8 Credit risk

Principle 9 Problem assets, provisions and reserves

Principle 10 Large exposure limits
IFSB Core Principles for Islamic Finance

Regulation (CPIFR)

Core Principles for Islamic Finance Regulation Working Group (CPIFRWG)

January 2016 or later

To provide a set of core principles for regulation and supervision, taking into consideration the specificities of Islamic banks and complementing the BCP compliance standards. Retained unchanged

Clear definition of licensed Islamic banks' permissible activities that are subject to supervision by regulatory authorities.

Retained unchanged

Retained unchanged

The regulatory authority has the power to approve or reject, and impose more prudential requirements on major acquisitions, against prescribed criteria, including the establishment of cross-border operations, and to determine that corporate affiliations or structures do not expose the bank to undue risks or hinder effective supervision.

Regulatory capital should be compliant with Sharia'a law. Accordingly, regulatory authorities require Islamic banks to adopt an appropriate capital adequacy approach by considering the particularities of Islamic banks (the extent of risk-sharing between bank shareholders (bank capital) and IAHs (depositors)). Regulatory authorities require Islamic banks to establish a comprehensive risk management process, including an effective board of directors and senior management, appropriate steps to comply with Sharia'a law, and the development of contingency arrangements. This process depends on the Islamic banks' risk profile and their systemic importance.

Regulatory authorities require Islamic banks to create an adequate credit risk management process (taking into account a bank's risk appetite, its risk profile, and market and macroeconomic conditions) that covers the full credit lifecycle including credit underwriting, credit evaluation, and the management of Islamic banks' financing and investment portfolios on a timely basis.

Islamic banks should implement adequate policies to identify assets at risk early-on and to maintain an adequate amount of provisions and reserves.

Regulatory authorities determine whether Islamic banks have adequate policies to identify, measure, and control concentrations of 
Table 12 (continued)

Principle 11 Exposures to related parties

$\begin{array}{ll}\text { Principle } 12 & \text { Country and transfer risks } \\ \text { Principle } 13 & \text { Market risk }\end{array}$

Principle 14 Liquidity risk

Principle 15 Operational risk

Principle 16 Interest rates in the banking book

Principle 17 Internal control and audit

Principle 18 Abuse of financial services

Principle 19 Supervisory approach

Principle 20 Supervisory techniques

Principle 21 Supervisory reporting risk. Regulators also set prudential limits to restrict bank exposures to single counterparties or groups of connected counterparties.

To prevent the risk of conflict of interest with related parties, the supervisory authority requires Islamic banks to monitor transactions with these parties, to take appropriate steps to control or mitigate the risks, and to write off exposures in accordance with standard policies and processes.

Retained unchanged

Regulatory authorities determine whether Islamic banks have adequate market risk management (taking into account a bank's risk appetite, its risk profile, and market and macroeconomic conditions) to identify, measure, and control market risk on a timely basis.

Regulatory authorities provide the appropriate liquidity instruments for the needs of Islamic banks. These authorities also determine whether Islamic banks have adequate liquidity risk management (taking into account a bank's risk appetite, its risk profile, and market and macroeconomic conditions) to identify, measure, and control liquidity risk on a timely basis.

Regulatory authorities determine whether Islamic banks have an adequate operational risk management framework (taking into account a bank's risk appetite, its risk profile, and market and macroeconomic conditions) to identify, measure, and control operational risk on a timely basis.

Rate of return risk instead of interest rates in the banking book. Regulatory authorities determine whether Islamic banks have an adequate system (taking into account a bank's risk appetite, its risk profile, and market and macroeconomic conditions) to identify, measure, and control rate of return risk on a timely basis. Regulators can also assess the capacity of an Islamic bank to manage the rate of return risk and any resultant displaced commercial risk, and to obtain sufficient information to assess the behavior of IAHs and their maturity profiles. Regulatory authorities determine whether Islamic banks have adequate internal control frameworks to establish and maintain a properly controlled operating environment for the conduction of their business taking into account their risk profile.

Retained unchanged

Retained unchanged

Regulatory authorities employ adequate instruments to implement their supervisory approach taking into account the risk profile and systemic importance of an Islamic bank. 
Table 12 (continued)

Principle 22 Accounting and disclosure

Principle 23 Corrective and remedial powers of supervisors

Principle 24 Consolidated supervision

Principle 25 Home-host relationships

Principle 26 Not applicable

Principle 27 Not applicable

Principle 28 Not applicable
The supervisory authority collects, reviews, and analyzes prudential reports and statistical returns from Islamic banks on both a solo and a consolidated basis, and independently verifies these reports through either on-site examinations or the use of external experts.

Retained unchanged

Regulatory authorities possess a range of tools to take corrective actions at an early stage to address unsafe practices or activities that could pose risks to an Islamic bank or to the banking system, i.e., the ability to revoke a banking license or to recommend its revocation. Regulatory authorities supervise the banking group on a consolidated basis; they adequately monitor and apply prudential standards to all aspects of the business conducted by the banking group worldwide.

Home and host regulatory authorities of cross-border banking groups share information and cooperate for effective supervision of the group and group entities. Supervisory authorities require the local operations of foreign Islamic banks to be conducted to the same standards as those required of a domestic Islamic bank.

Treatment of Investment Account Holders (IAHs). The regulatory authorities determine how IAHs are treated and also determine the various implications (including the regulatory treatment, governance and disclosures, and capital adequacy and associated risk-absorbency features, etc.) relating to IAHs within their jurisdiction.

Sharia'a governance framework. Regulatory authorities determine whether Islamic banks have a robust Sharia'a governance system to ensure an effective independent oversight of Sharia'a compliance over various structures and processes within the organizational framework. The Sharia'a governance structure adopted by an institution offering Islamic financial services is commensurate and proportionate with the size, complexity, and nature of its business. The supervisory authority also determines the general approach to Sharia' $a$ governance in its jurisdiction, and lays down key elements of the process.

Equity investment risk. Regulatory authorities satisfy themselves through adequate policies and procedures including appropriate strategies, risk management and reporting processes for equity investment risk management, including Mudarabah and Musharakah investments in the banking book (i.e., financing on a profit-and-loss sharing basis), taking into account Islamic banks' appetite and tolerance for risk. In addition, the supervisory authority 
Table 12 (continued)

Principle 29 Not applicable ensures that Islamic banks: have in place appropriate and consistent valuation methodologies; define and establish the exit strategies in respect of their equity investment activities; and have sufficient capital when engaging in equity investment activities.

Islamic "windows" operations. Supervisory authorities define what forms of Islamic "windows" are permitted in their jurisdictions. The supervisory authorities review Islamic windows' operations within their supervisory review process using the existing supervisory tools. The supervisory authorities in jurisdictions where windows are present satisfy themselves that the institutions offering such windows have the internal systems, procedures and controls to provide reasonable assurance that: (i) the transactions and dealings of the windows are in compliance with Sharia'a rules and principles; (ii) appropriate risk management policies and practices are followed; (iii) Islamic and non-Islamic business are properly segregated; and (iv) the institution provides adequate disclosures for its window operations. 
Table 13 Variable definitions

\begin{tabular}{|c|c|c|}
\hline Variable & Definition & Data sources \\
\hline Z-score & $\begin{array}{l}\text { A measure of bank insolvency calculated as the } \\
\text { natural logarithm of ((ROAA+TETA)/SDROAA), } \\
\text { where ROAA is the return on average assets, TETA } \\
\text { represents the equity to assets ratio and SDROAA } \\
\text { stands for the standard deviation of the return on } \\
\text { average assets. }\end{array}$ & Authors' calculations \\
\hline AROAA & $\begin{array}{l}\text { A measure of risk-adjusted return on average assets. } \\
\text { It is calculated as the return on average assets } \\
\text { (ROAA) divided by the standard deviation of } \\
\text { ROAA. }\end{array}$ & Authors' calculations \\
\hline LLRGL & $\begin{array}{l}\text { Bank reserves for loan losses divided by gross loans, } \\
\text { multiplied by } 100\end{array}$ & Authors' calculations \\
\hline LLPTL & $\begin{array}{l}\text { Bank provisions for loan losses divided by total } \\
\text { loans, multiplied by } 100\end{array}$ & Authors' calculations \\
\hline NPLGL & $\begin{array}{l}\text { Bank non-performing loans divided by gross loans, } \\
\text { multiplied by } 100\end{array}$ & Authors' calculations \\
\hline SDNIM & $\begin{array}{l}\text { The standard deviation of the net interest margin for } \\
\text { a three-year period }\end{array}$ & Authors' calculations \\
\hline $\operatorname{lnta}$ & The natural logarithm of total assets & Bankscope \\
\hline gta & $\begin{array}{l}\text { The current year growth rate of bank total assets } \\
\text { compared with the previous year's total assets. }\end{array}$ & Bankscope \\
\hline cir & $\begin{array}{l}\text { The ratio of bank costs to bank income before } \\
\text { provisions, multiplied by } 100\end{array}$ & Bankscope \\
\hline niiti & $\begin{array}{l}\text { Bank noninterest income to bank total operating } \\
\text { income, multiplied by } 100\end{array}$ & Authors' calculations \\
\hline ladstf & $\begin{array}{l}\text { The ratio of liquid assets to deposits and short term } \\
\text { funding. It measures and assesses the sensitivity to } \\
\text { bank runs; therefore, it promotes financial soundness } \\
\text { but it can also be interpreted as excess liquidity } \\
\text { coverage. }\end{array}$ & Bankscope \\
\hline
\end{tabular}

BCP index An overall index of BCP compliance. The index takes on values between 25 and 100, with higher values suggesting greater compliance with the BCPs.

Chapter 1 This variable is the normalized sum of the rates of compliance with the sub-principles of principle 1 and measures the extent to which the preconditions for effective banking supervision have been met: 1(1): There should be clear responsibilities and objectives set by legislation for each supervisory agency; 1(2): Each supervisory agency should possess adequate resources to meet the objective set, provided that they do not undermine the autonomy, integrity, and independence of the supervisory agency; 1(3): There should be a suitable framework of banking laws setting bank minimum standards, including provisions related to the authorization of banking establishments and their supervision; 1(4): The legal framework should provide the power to address compliance with laws as well as safety and soundness concerns; 1(5): The legal framework should provide protection of supervisors for actions taken in good faith in the course of performing supervisory duties; and 1(6): There should be arrangements for interagency cooperation, including with foreign supervisors, for sharing information and protecting the confidentiality of such information.

IMF/World Bank Basel Core Financial Sector Assessment Program (FSAP) database

IMF/World Bank Basel Core Financial Sector Assessment Program (FSAP) database 
Table 13 (continued)

Variable Definition Data sources

The variable takes on values between 25 and 100 , with higher values indicating better adherence to these preconditions.

Chapter 2 This variable is the normalized sum of the rates of compliance with principles 2-5; 2: Definition of permissible activities; 3 : Right to set licensing criteria and reject applications for establishments that do not meet the standards set; 4: Authority to review and reject proposals for significant ownership changes; and 5: Authority to establish criteria for reviewing major acquisitions or investments. The variable takes on values between 25 and 100, with higher values indicating greater power of supervisors to approve a license and influence the structure of the new banking entity.

Chapter 3 This variable measures the prudence and appropriateness of the minimum capital adequacy requirements that supervisors set. The variable is the normalized sum of the rates of compliance with principles 6-15: 6: Prudent and appropriate risk-adjusted capital adequacy ratios must be set; 7 : Supervisors should evaluate banks' credit policies; 8: Banks should adhere to adequate loan evaluation and loan-loss provisioning policies; 9: Supervisors should set limits to restrict large exposures, and concentration in bank portfolios should be identifiable; 10: Supervisors must have in place requirements to mitigate the risks associated with related lending; 11: Policies must be in place to identify, monitor, and control country risks, and to maintain reserves against such risks; 12: Systems must be in place to accurately measure, monitor, and adequately control markets risks, and supervisors should have powers to impose limits or capital charge on such exposures; 13: Banks must have in place a comprehensive risk management process to identify, measure, monitor, and control all other material risks and, if needed, hold capital against such risks; 14 : Banks should have internal control and audit systems in place; and 15: Adequate policies, practices, and procedures should be in place to promote high ethical and professional standards and prevent a bank being used by criminal elements. The variable takes on values between 25 and 100, with higher values indicating a greater compliance to the minimum capital requirements.

Chapter 4 This variable measures the extent of ongoing supervision. The variable is calculated as the normalized sum of the rates of compliance with principles 16-20: 16: An effective supervisory system should consist of on-site and off-site supervision; 17: Supervisors should have regular contact with bank management; 18: Supervisors must have the means of collecting, reviewing, and analyzing prudential reports and statistics from banks on a solo and consolidated basis; 19: Supervisors must have a means of independent validation of supervisory
IMF/World Bank Basel Core Financial Sector Assessment Program (FSAP) database

IMF/World Bank Basel Core Financial Sector Assessment Program (FSAP) database

IMF/World Bank Basel Core Financial Sector Assessment Program (FSAP) database 
Table 13 (continued)

Variable Definition Data sources

information, either through on-site examinations or the use of external auditors; and 20: Supervisors must have the ability to supervise banking groups on a consolidated basis. The variable takes on values between 25 and 100, with higher values suggesting higher levels of on-going supervision.

Chapter 5 A measure of the required extent of a bank's internal financial records. This variable is the normalized rate of compliance with principle 21: Each bank must maintain adequate records that enable the supervisor to obtain a true and fair view of the financial condition of the bank, and must publish on a regular basis financial statements that fairly reflect its condition. The variable takes on values between 25 and 100 , with higher values suggesting more stringent requirements for information disclosure.

\section{Chapter 6 A measure of the formal powers of supervisors,} calculated as the normalized rate of compliance with principle 22: Adequate supervisory measures must be in place to bring about corrective action when banks fail to meet prudential requirements, when there are regulatory violations, or when depositors are threatened in any other way. This should include the ability to revoke the banking license or recommend its revocation. The variable takes on values between 25 and 100, with higher values indicating greater supervisory powers.

Chapter 7 This variable measures the extent to which supervisors apply global consolidated supervision over internationally active banks. The variable is calculated as the normalized sum of the rates of compliance with principles 23-25: 23: Supervisors must practice global consolidated supervision over internationally active banks, and must adequately monitor and apply prudential norms to all aspects of the business conducted by these banks; 24 :

Consolidated supervision should include establishing contacts and information exchanges with the various supervisors involved, primarily the host country supervisory authorities; 25 : Supervisors must require the local operations of foreign banks to be conducted with the same standards as those required of domestic institutions, and must have powers to share information needed by the home country supervisors of those banks. The variable takes on values between 25 and 100, with higher values suggesting a stronger movement towards global consolidated supervision.

wgi The world governance index is the average of six governance dimensions including: (1) voice and accountability, (2) political stability and absence of violence, (3) government effectiveness, (4) regulatory quality, (5) rule of law, and (6) control of corruption (see Kaufmann et al. (2010) for details).

gdpg Growth rate of GDP

inf
IMF/World Bank Basel Core Financial Sector Assessment Program (FSAP) database

IMF/World Bank Basel Core Financial Sector Assessment Program (FSAP) database

IMF/World Bank Basel Core Financial Sector Assessment Program (FSAP) database

World governance indicators database (The World Bank and Kaufmann et al. (2010))

World Development Indicators (WDI) World Development Indicators (WDI) 
Table 13 (continued)

Variable Definition $\quad$ Data sources

oil

mineral

EIU credit risk The Economic Intelligence Unit (EIU) credit risk index

CRC index

ICRG index

D-to-D

Concentration

ratio

Market discipline

Inflation rate, based on changes in the consumer price index

Oil rents are the difference between the value of crude oil production at world prices and the total costs of production.

Natural gas rents are the difference between the value of natural gas production at world prices and the total costs of production.

Mineral rents are the difference between the value of production for a stock of minerals (tin, gold, lead, zinc, copper, nickel, silver, bauxite, and phosphate) at world prices and the total costs of production. index assesses the risk of cross-border transactions such as bank loans, trade finance and investment securities. Used by the credit risk departments of commercial banks, this index is the average of six country risk categories: (1) sovereign risk, (2) currency risk, (3) sovereign debt risk, (4) banking sector risk, (5) political risk, and (5) economic structure risk. The credit risk index scores range between 0 and 100 with higher values indicating greater credit risk exposure.

The Country Risk Classification (CRC) index measures the country credit risk and the likelihood that a country will repay its external debt. The index reflects transfer and convertibility risk as well as cases of force majeure. It ranges between 0 and 7 with higher values indicating greater credit risk exposure. The international Country Risk Guide (ICRG) index assesses three subcategories of risk: (1) political risk, (2) financial risk, and (3) economic risk. Used by banks and multinational corporations, the ICRG index determines how financial, economic, and political risk might affect their business and investments now and in the future. The ICRG index ranges between 0 and 100 with higher values indicating less risk exposure.

The Moody's KMV distance to default is based on the Expected Default Frequency and is a measure of the probability that a bank will default over a specific period of time (typically one year). There are three key values that determine a bank's EDF credit measure: (1) the current market value of the bank (market value of assets), (2) the level of the bank's obligations (default point), and (3) the vulnerability of the market value to changes (assets volatility).

Concentration of the three biggest banks in a country according to their share of total assets

Market discipline and private monitoring is an indicator of disclosure of adequate information to the market. It ranges from 0 to 9 and is calculated by responding to the following 9 questions ( 1 if the answer is yes and 0 otherwise except for questions 8 and 9 where the opposite occurs): (1) Is subordinated debt allowed (or required) as capital? (2) Are
World Development Indicators (WDI)

World Development Indicators (WDI)

World Development Indicators (WDI)

The Economist - Economic Intelligence Unit

www.OECD.org website - Country Risk Classification

www.prsgroup.com website - International Country Risk Guide

Moody's Analytics and authors' calculations

Authors' calculations

Banking Regulation and Supervision database, World Bank, and authors' calculations 
Table 13 (continued)

\begin{tabular}{|c|c|c|}
\hline Variable & Definition & Data sources \\
\hline & $\begin{array}{l}\text { financial institutions required to produce consolidat- } \\
\text { ed accounts covering all bank and any non-bank } \\
\text { financial subsidiaries? ( } 3 \text { ) Are off-balance-sheet } \\
\text { items disclosed to the public? (4) Must banks dis- } \\
\text { close their risk-management procedures? (5) Are } \\
\text { directors legally liable for erroneous/misleading in- } \\
\text { formation? (6) Do regulations require credit ratings } \\
\text { for commercial banks? (7) Is an external audit by a } \\
\text { certified/licensed auditor mandatory for banks? (8) } \\
\text { Does accrued, unpaid interest/principal on } \\
\text { non-performing loans appear on the income state- } \\
\text { ment? (9) Is there an explicit deposit-insurance pro- } \\
\text { tection system? }\end{array}$ & \\
\hline $\begin{array}{l}\text { Entry } \\
\text { requirements }\end{array}$ & $\begin{array}{l}\text { This variable is based on surveys by Barth et al. } \\
\text { (2000, 2003, 2008, see details therein). The variable } \\
\text { increases by } 1 \text { if the answer is yes to questions } 1-8 \\
\text { of their survey, with no increase if the answer is no. } \\
\text { The variable addresses } 8 \text { questions with higher } \\
\text { values indicating stricter entry requirements: Re- } \\
\text { garding the legal submissions required for a banking } \\
\text { license: (1) Is the legal submission drafted by-laws? } \\
\text { (2) Does the legal submission require an intended } \\
\text { organization chart? (3) Does the legal submission } \\
\text { require first 3-year financial projections? (4) Does } \\
\text { the legal submission require financial information on } \\
\text { shareholders? (5) Does the legal submission require } \\
\text { background/experience of future directors? (6) Does } \\
\text { the legal submission require background/experience } \\
\text { of future managers? (7) Does the legal submission } \\
\text { require sources of funds in capitalization of the new } \\
\text { bank? (8) Does the legal submission require infor- } \\
\text { mation on the intended market differentiation of the } \\
\text { new bank? }\end{array}$ & $\begin{array}{l}\text { Banking Regulation and Supervision } \\
\text { database, World Bank, and authors' } \\
\text { calculations }\end{array}$ \\
\hline $\begin{array}{l}\text { Financial } \\
\text { freedom index }\end{array}$ & $\begin{array}{l}\text { The financial freedom index measures the efficiency } \\
\text { of the overall banking system. It examines a broad } \\
\text { category of indicators, including the extent of } \\
\text { financial and market development, the extent of } \\
\text { government regulation of financial services, and } \\
\text { openness to foreign competition. The index varies } \\
\text { between } 0 \text { and } 100 \text { with higher values indicating } \\
\text { better economic and financial conditions. }\end{array}$ & Heritage Foundation \\
\hline
\end{tabular}

Open Access This article is licensed under a Creative Commons Attribution 4.0 International License, which permits use, sharing, adaptation, distribution and reproduction in any medium or format, as long as you give appropriate credit to the original author(s) and the source, provide a link to the Creative Commons licence, and indicate if changes were made. The images or other third party material in this article are included in the article's Creative Commons licence, unless indicated otherwise in a credit line to the material. If material is not included in the article's Creative Commons licence and your intended use is not permitted by statutory regulation or exceeds the permitted use, you will need to obtain permission directly from the copyright holder. To view a copy of this licence, visit http://creativecommons.org/licenses/by/4.0/. 


\section{References}

Abedifar P, Molyneux P, Tarazi A (2013) Risk in Islamic banking. Rev Financ 17:2035-2096

Ayadi R, Ben Naceur S, Casu B, Quinn B (2016) Does Basel compliance matter for bank performance? J Financ Stab 23:15-32

Barth JR, Caprio G, Levine R (2004) Bank regulation and supervision: what works best? J Financ Intermed 13: 205-248

Barth JR, Caprio G, Levine R (2006) Rethinking bank regulation: till angels govern. Cambridge University Press, Cambridge, UK

Barth JR, Caprio G, Levine R (2008) Bank regulations are changing: for better or worse? Comp Econ Stud 50: 537-563

Barth J, Lin C, Lin P, Song FM (2009) Corruption in bank lending to firms: cross-country micro evidence on the beneficial role of competition and information sharing. J Financ Econ 91:361-388

Barth J, Lin C, Ma Y, Seade J, Song F (2013) Do bank regulation, supervision and monitoring enhance or impede bank efficiency? J Bank Financ 37:2879-2892

Beck T, Demirgüç-Kunt A, Merrouche O (2013) Islamic vs. conventional banking: business model, efficiency and stability. J Bank Financ 37:433-447

Beck T, Demirgüç-Kunt A, Levine R (2003) Law, endowments, and finance. J Financ Econ 70:137-181

Bitar M, Tarazi A (2019) Creditor rights and bank capital decisions: conventional vs. Islamic banking. Journal of Corporate Finance 55:69-104

Bitar M, Hassan MK, Walker T (2017) Political systems and the financial soundness of Islamic banks. J Financ Stab 31:18-44

Bitar M, Kabir MK, Hippler WJ (2018) The determinants of Islamic bank capital decisions. Emerg Mark Rev 35 : 48-68

Bitar M, Saad W, Benlemlih M (2016) Bank risk and performance in the MENA region: the importance of capital requirements. Econ Syst 40:398-421

Carretta A, Farina V, Fiordelisi F, Schwizer P, Lopes F (2015) Don't stand so close to me: the role of supervisory style in banking stability. J Bank Financ 52:180-188

Cihak M, Tieman A (2008) Quality of financial sector regulation and supervision around the world, IMF working paper 08/190. International Monetary Fund, Washington

Demirgüç-Kunt A, Detragiache E (2011) Basel core principles and bank soundness: does compliance matter? J Financ Stab 7:179-190

Demirgüç-Kunt A, Detragiache E, Tressel T (2008) Banking on the principles: compliance with Basel Core principles and bank soundness. J Financ Intermed 17:511-542

Djankov S, McLiesh C, Shleifer A (2007) Private credit in 129 countries. J Financ Econ 84:299-329

Doumpos M, Gaganis C, Pasiouras F (2015) Central bank independence, financial supervision structure and bank soundness: an empirical analysis around the crisis. J Bank Financ 61:S69-S83

Gheeraert L (2014) Does Islamic finance spur banking sector development? J Econ Behav Organ 103:S4-S20

Groeneveld H, de Vries B (2009) European co-operative banks: first lessons of the subprime crisis. Int J CoOperative Manag 4:8-21

Heckman JJ (1979) Sample selection bias as a specification error. Econometrica 47:153-161

Horváth R, Seidler J, Weill L (2014) Bank capital and liquidity creation: granger causality evidence. J Financ Serv Res 45:341-361

Houston JF, Lin C, Lin P, Ma Y (2010) Creditor rights, information sharing, and bank risk taking. J Financ Econ 96:485-512

Islamic Financial Services Board (2015). Core principles for Islamic finance regulation (banking segment) (CPIFR)

Kaufmann D, Kraay A, Mastruzzi M (2010) The worldwide governance indicators: methodology and analytical issues. Policy research working paper, no. WPS 5430. World Bank

Khan F (2010) How Islamic is Islamic banking? J Econ Behav Organ 76:805-820

Klomp J, de Haan J (2012) Banking risk and regulation: does one solution fit all? J Bank Financ 36:3197-3212

Klomp J, de Haan J (2014) Bank regulation, the quality of institutions, and banking risk in emerging and developing countries: an empirical analysis. Emerging Market Financ Trade 50:19-40

Leaven L, Levine R (2009) Bank governance, regulation and risk taking. J Financ Econ 93:259-275

Mollah S, Zaman M (2015) Shari'ah supervision, corporate governance, and performance: conventional vs. Islamic banks. J Banking Finance 58:418-435

Mollah S, Hassan K, Al-Farooque O, Mobarek A (2017) The governance, risk-taking, and performance of Islamic banks. J Financ Serv Res 51:195-219

Nichols A, Schaffer ME (2007) Clustered standard errors in Stata. In: United Kingdom Stata users' group meetings 2007. Group, Stata Users 
Öztekin Ö (2015) Capital structure decisions around the world: which factors are reliably important? J Financ Quant Anal 50:301-323

Podpiera R (2006) Does compliance with basel core principles bring any measurable benefits? IMF Staff Papers 53:306-326

Rosenbaum PR, Rubin DB (1983) The central role of the propensity score in observational studies for causal effects. Biometrika 70:41-55

Sundararajan V, Marston D, Basu R (2001) Financial system standards and financial stability - the case of Basel Core principles, IMF working paper 01/62. International Monetary Fund, Washington

Vazquez F, Federico P (2015) Bank funding structures and risk: Evidence from the global financial crisis.Journal of Banking \& Finance 61, 1-14

Publisher's Note Springer Nature remains neutral with regard to jurisdictional claims in published maps and institutional affiliations. 